This document is the accepted manuscript version of the following article:

E. Bernard, B. Lothenbach, D. Rentsch, I. Pochard, A. Dauzères (2017). Formation of magnesium silicate hydrates (M-S-H). Physics and Chemistry of the Earth.

http://dx.doi.org/10.1016/j.pce.2017.02.005

This manuscript version is made available under the CC-BY-NC-ND 4.0

license http://creativecommons.org/licenses/by-nc-nd/4.0/

\title{
Formation of magnesium silicate hydrates (M-S-H)
}

Ellina Bernard ${ }^{\mathrm{a}}$, Barbara Lothenbach ${ }^{\mathrm{a}}$, Daniel Rentsch ${ }^{\mathrm{b}}$, Isabelle Pochard ${ }^{\mathrm{c}}$, Alexandre Dauzères ${ }^{\mathrm{d}}$

${ }^{a}$ Empa, Laboratory for Concrete \& Construction Chemistry, 8600 Dübendorf, Switzerland

${ }^{\mathrm{b}}$ Empa, Laboratory for Functional Polymers, 8600 Dübendorf, Switzerland

${ }^{c}$ Université Bourgogne-Franche-Comté, 21078 Dijon, France

d IRSN, Institute of Radiation Protection and Nuclear Safety, BP 17, 92262 Fontenay aux Roses, France

Corresponding author: Bernard E., email: ellina.bernard@empa.ch

\section{Abstract}

The formation of magnesium silicate hydrates $(\mathrm{M}-\mathrm{S}-\mathrm{H})$ with $\mathrm{MgO}$ to $\mathrm{SiO}_{2}$ ratios from 0.7 to 1.6 has been studied at 20,50 and $70^{\circ} \mathrm{C}$. TGA and XRD data reveal that initially brucite and M-S-H are formed while amorphous silica is still present as indicated by FT-IR and ${ }^{29}$ Si MAS NMR experiments. In this first step $\mathrm{M}-\mathrm{S}-\mathrm{H}$ with $\mathrm{Mg} / \mathrm{Si} \sim 1$ with $\mathrm{pH}$ values $\sim 9.4$ is formed independently of the total $\mathrm{Mg} / \mathrm{Si}$. Investigations by FT-IR and ${ }^{29} \mathrm{Si}$ MAS NMR detail that the structure of that initial M-S-H evolved with time and M-S-H formed with $\mathrm{Mg} / \mathrm{Si}$ ranging from 0.8 to $\sim 1.3$ after 2 years at $20^{\circ} \mathrm{C}$ and after 1 year at 50 and $70^{\circ} \mathrm{C}$. This implies that the composition of synthetic M-S-H depends strongly on temperature and equilibration time. At 50 and $70^{\circ} \mathrm{C}$ the $\mathrm{M}-\mathrm{S}-\mathrm{H}$ formation occurs faster although it is thermodynamically slightly less stable. The solubility of M$\mathrm{S}-\mathrm{H}$, talc and antigorite after 1 year or longer shows comparable trends.

\section{Introduction}

An accumulation of magnesium has been observed at the interface of cement with natural rocks (clayey or granitic rocks), which contain magnesium (Dauzères et al., 2014; Garcia Calvo et al., 
2010; Jenni et al., 2014). Recent investigations suggest that these Mg-enrichment are based on the formation of magnesium silicate hydrate phases (M-S-H; short for $\mathrm{M}_{\mathrm{x}}-\mathrm{S}_{\mathrm{y}}-\mathrm{H}_{\mathrm{z}}$ : $(\mathrm{MgO})_{\mathrm{x}}{ }^{-}$ $\left(\mathrm{SiO}_{2}\right)_{\mathrm{y}}-\left(\mathrm{H}_{2} \mathrm{O}\right)_{\mathrm{z}}$ gel with variable composition) (Dauzères et al., 2016), possibly accompanied by the formation of hydrotalcite (Jenni et al., 2014).

Such M-S-H phases have also been synthesized in the laboratory in order to be able to study their properties and solubility (Brew and Glasser, 2005b; d'Espinose de Lacaillerie et al., 1995; Nied et al., 2016; Roosz et al., 2015; Walling et al., 2015). M-S-H is a semi-amorphous phase with characteristic broad peaks observed by XRD at 19.7 (110), 26.7, 35.0 (201) and 59.9 (060) ${ }^{\circ} 2$ theta $(\lambda=1.54 \AA \hat{\text { ) }}$ (Roosz et al., 2015). Investigations of the structure of M-S-H gels (Brew and Glasser, 2005b; d'Espinose de Lacaillerie et al., 1995; Nied et al., 2016; Roosz et al., 2015; Walling et al., 2015) by FT-IR and/or ${ }^{29}$ Si MAS NMR show a high polymerization degree of the Si-network in M-S-H. Mainly $\mathrm{Q}^{3}$ silicate sites have been observed in M-S-H indicating a layered silica structure as found in clay minerals. The structure of M-S-H is unclear and has been related to sepiolite (Brew and Glasser, 2005b) hydrated nanoparticles of talc (Roosz et al., 2015), hydrated talc or hydrated antigorite (Nied et al., 2016), or compared to lizardite (Walling et al., 2015). All these minerals belong either to the serpentine group mineral with T:O structure (= Tetrahedral silica : Octahedral magnesium sheet) (antigorite, lizardite) or to the mineral group with a T:O:T structure (talc, sepiolite), depending on the content of magnesium in the structure.

Under laboratory conditions M-S-H formation has been observed to be very slow (Li et al., 2014; Szczerba et al., 2013; Zhang et al., 2011). Studies on the formation of synthetic M-S-H from $\mathrm{MgO}$ and silica fume (Li et al., 2014; Szczerba et al., 2013; Zhang et al., 2011) indicate that initially magnesium hydroxide, i.e. brucite, is formed, which subsequently reacts to form M-S-H phases. The magnesium hydroxide dissolves slowly in the presence of M-S-H; it takes up to 6 
months for initially precipitated magnesium hydroxide to completely react to $\mathrm{M}-\mathrm{S}-\mathrm{H}$ with $\mathrm{Mg} / \mathrm{Si}=1$ (Szczerba et al., 2013).

A number of factors seem to influence the kinetics: i) a higher temperature leads to faster formation of M-S-H and the destabilization of brucite (Brew and Glasser, 2005b; Golubeva et al., 2005; Kalousek and Mui, 1954; Szczerba et al., 2013), ii) the magnesium to silica ratio of the magnesium silicate phases is increased at higher temperature (Kalousek and Mui, 1954), iii) the properties of the starting materials have a strong impact on the kinetics. Magnesium oxide reacts faster than brucite (Yang, 1960) and $\mathrm{MgO}$ calcined at lower temperature or with a higher specific surface area reacts even faster (Jin and Al-Tabbaa, 2013; Yang, 1960). Not only the temperature or the initial raw materials but also the water to solid ratio (W/S) and the $\mathrm{Mg} / \mathrm{Si}$ ratio seem to influence the kinetics of M-S-H formation (Brew and Glasser, 2005b; d'Espinose de Lacaillerie et al., 1995; Jin and Al-Tabbaa, 2013; Kalousek and Mui, 1954; Nied et al., 2016; Wei et al., 2011; Zhang et al., 2011). In addition it can be expected that also the $\mathrm{pH}$ value could have an influence, as higher $\mathrm{pH}$ values increase dissolution kinetics of silica (Brantley et al., 2008) but slow down brucite dissolution (Pokrovsky and Schott, 2004). Most studies on M-S-H were carried out on samples equilibrated up to 1 year (Nied et al., 2016; Roosz et al., 2015) or even less (Brew and Glasser, 2005a; Brew and Glasser, 2005b; d'Espinose de Lacaillerie et al., 1995; Li et al., 2014; Szczerba et al., 2013; Zhang et al., 2011) under ambient conditions, i.e. under conditions where $\mathrm{M}-\mathrm{S}-\mathrm{H}$ has not yet reached equilibrium. Longer equilibration times and/or higher temperatures are needed to investigate the effect of $\mathrm{Mg} / \mathrm{Si}$ on the $\mathrm{M}-\mathrm{S}-\mathrm{H}$ formation. Thus, the present paper studies the effect of the initial $\mathrm{Mg} / \mathrm{Si}$ on the formation of $\mathrm{M}-\mathrm{S}-\mathrm{H}$ and on its structure and solubility up to 2 years at $20^{\circ} \mathrm{C}$ and up to 1 year at 50 and $70^{\circ} \mathrm{C}$. Solubility products of two end members were calculated based on the measured concentrations and $\mathrm{pH}$ values. 


\section{Materials and methods}

\subsection{Materials and synthesis}

Magnesium oxide (Merck, pro analysis, $0.18 \pm 0.02$ wt.\% $\left.\mathrm{Na}_{2} \mathrm{O}\right)$ and silica fume $\left(\mathrm{SiO}_{2}\right.$, Aerosil 200, 0.9wt.\% $\mathrm{HCl}$ ) were chosen as starting materials. The total $\mathrm{Mg} / \mathrm{Si}$ varied between 0.7 and 1.6 and synthesis were optimized to obtain $\sim 5 \mathrm{~g}$ of $\mathrm{M}-\mathrm{S}-\mathrm{H}$ (Table 1). The impurities in the starting $\mathrm{SiO}_{2}$ and $\mathrm{MgO}$ resulted in approximately $0.03 \mathrm{mM}[\mathrm{Cl}]$ and $0.7 \mathrm{mM}[\mathrm{Na}]$ in the solution of the $\mathrm{Mg} / \mathrm{Si}=0.8$ sample. The specific surface area $(\mathrm{BET})$ of the magnesium oxide equals to $24 \mathrm{~m}^{2} / \mathrm{g}$ which corresponds to a good $\mathrm{MgO}$ reactivity (Jin and Al-Tabbaa, 2013). M-S-H samples were prepared in PE-HD containers using milli-Q water and a water/solid (W/S) ratio of 45 to ensure a homogeneous suspension and sufficient solution for analysis. All sample handling was done in a glove box under $\mathrm{N}_{2}$ to avoid $\mathrm{CO}_{2}$ contamination. The samples equilibrated at $20^{\circ} \mathrm{C}$ were placed on a horizontal shaker, the samples at $50^{\circ} \mathrm{C}$ and $70^{\circ} \mathrm{C}$ were manually shaken once a week.

In addition two $\mathrm{M}-\mathrm{S}-\mathrm{H}(\mathrm{Mg} / \mathrm{Si}=0.8$ and 1.2$)$ samples previously equilibrated at $50^{\circ} \mathrm{C}$ during 1 year were mixed with milliQ-water and kept at $7^{\circ} \mathrm{C}$ for 18 months to equilibrate again at $7^{\circ} \mathrm{C}$ and analysed. Solubility data at $7^{\circ} \mathrm{C}$ were calculated to extend the solubility data to lower temperatures as well.

Table 1: Starting materials for the different $M g / S i$ of $M-S-H$ samples (g=grams; $M g / S i=$ molar magnesium to silica ratio)

\begin{tabular}{ccccccccccc}
\hline $\mathrm{Mg} / \mathrm{Si}$ & 0.7 & 0.8 & 0.9 & 1 & 1.1 & 1.2 & 1.3 & 1.4 & 1.5 & 1.6 \\
\hline $\mathrm{MgO}[\mathrm{g}]$ & 1.60 & 1.75 & 1.88 & 2.01 & 2.12 & 2.23 & 2.33 & 2.42 & 2.51 & 2.59 \\
$\mathrm{SiO}_{2}[\mathrm{~g}]$ & 3.40 & 3.25 & 3.12 & 2.99 & 2.88 & 2.77 & 2.67 & 2.58 & 2.49 & 2.41 \\
\hline
\end{tabular}

After 1, 3, 6, 12 and 24 months, the suspensions were separated by filtration using pressure (4-5 bars $\mathrm{N}_{2}$ ) filtration and nylon filters $(0.45 \mu \mathrm{m})$. The solids were washed with a $50 / 50$ (volume) 
water-ethanol mix and a second time with ethanol (94wt $\%$ alcohol) to eliminate dissolved ions and to prevent the precipitation of salts during drying which could perturb the analyses. The samples were dried by freezing with liquid nitrogen (around $20 \mathrm{~min}$ at $-195^{\circ} \mathrm{C}$ ) and $\mathrm{kept}$ at $-40^{\circ} \mathrm{C}$ under 0.280 mbar pressure (vacuum) for further 7 days in a freeze dryer. The freeze drying minimizes carbonation as it removes free water efficiently. The solid characterizations were performed after further equilibration in $\mathrm{N}_{2}$ filled desiccators over saturated $\mathrm{CaCl}_{2}$ solution for a period of 14 days or longer to ensure $\sim 30 \% \mathrm{RH}$ in all the samples. After drying the samples were gently ground by hand.

For comparison, also crystalline magnesium silicate hydrates such as synthetic talc $(\mathrm{Mg} / \mathrm{Si}=0.75)$ (Alfa Aesar), natural antigorite $(\mathrm{Mg} / \mathrm{Si}=1.5)$ (from the location Geisspfad, Binntal) and natural sepiolite $(\mathrm{Mg} / \mathrm{Si}=0.67)$ (from the location Kaffa, Crimea) were studied. Small amounts of the synthetic talc and natural antigorite samples were ground, mixed with milliQ-water at a W/S of 20 and after an equilibration time of $\sim 1$ year, their solution composition was analysed to determine their solubility at $20^{\circ} \mathrm{C}$.

\subsection{Analytical techniques}

The composition of the liquid phase was analysed by ion chromatography (IC) immediately after filtration. The dissolved concentrations of $\mathrm{Mg}, \mathrm{Si}, \mathrm{Na}$, and $\mathrm{Cl}$ in undiluted solutions or in solutions diluted by factors 10 were quantified using a Dionex DP serie ICS-3000 ion chromatography system. Independent measurements of solutions with known compositions indicated a measurement error $\leq 8 \%$. All concentrations were determined in duplicates and hence, the mean values are given. The $\mathrm{pH}$ value measured in filtrated solution can be lower than the $\mathrm{pH}$ values measured directly in the suspension as charge balancing anions, such as hydroxides, can be removed during the filtration (Nied et al., 2016; Plusquellec, 2014). Therefore, the $\mathrm{pH}( \pm 0.1)$ 
was measured in the supernatant at ambient temperature $\left(23 \pm 2^{\circ} \mathrm{C}\right)$ in an aliquot of the unfiltered suspension where the solid particles had been allowed to settle. The measured $\mathrm{pH}$ values were corrected to 20,50 or $70^{\circ} \mathrm{C}$. No significant changes in the aqueous phase composition is expected within the 30 minutes used to cool down the solutions from 50 and $70^{\circ} \mathrm{C}$ to ambient temperature, as M-S-H precipitation occurs only very slowly and as no significant differences in the measured concentrations between diluted and not-diluted solutions were observed.

Thermogravimetric analyses (TGA) were carried out on ground powder ( 30 mg) with a Mettler Toledo TGA/SDTA 8513 instrument using a heating rate of $20^{\circ} \mathrm{C} / \mathrm{min}$ from 30 to $980{ }^{\circ} \mathrm{C}$. The amount of $\mathrm{Mg}(\mathrm{OH})_{2}$ (brucite) was quantified from the water weight loss at around $400-420^{\circ} \mathrm{C}$ using the tangential method (Lothenbach et al., 2016) and calculated according to the equation (1):

$$
\text { wt. } \% \text { brucite }_{\text {dry }}=\frac{\text { water loss }(\text { brucite })}{100-\text { water } \operatorname{loss}_{\left(30-550^{\circ} \mathrm{C}\right)}} \times \frac{M_{\text {brucite }}}{M_{\mathrm{H} 2 \mathrm{O}}} \times 100
$$

wt. \% brucite ${ }_{\text {dry }}$ corresponds to the wt.\% of brucite for $100 \mathrm{~g}$ of dry mass water loss in wt. \% $M_{\text {brucite }}=58.32 \mathrm{~g} / \mathrm{mol}$ $M_{H 2 O}=18.02 \mathrm{~g} / \mathrm{mol}$

The relative error on the brucite content is $\pm 5-10 \%$ (Deschner et al., 2012; Lothenbach et al., 2016). The total water bound in M-S-H was quantified from the total water loss between 30 and $980^{\circ} \mathrm{C}$ and the water associated to hydroxyl groups in $\mathrm{M}-\mathrm{S}-\mathrm{H}$ was quantified from the water loss between 270 and $800^{\circ} \mathrm{C}$. Both results were normalized to the dry weight and corrected for the amount of brucite; the results are given per silicon. 
X-ray diffraction (XRD) data were collected using a PANalytical X'Pert Pro MPD diffractometer equipped with a rotating sample stage in a theta- 2 theta configuration applying $\mathrm{CuK} \alpha$ radiation $(\lambda=1.54 \AA)$ at $45 \mathrm{mV}$ voltage and $40 \mathrm{~mA}$ intensity with a fixed divergence slit size and an antiscattering slit on the incident beam of $0.5^{\circ}$ and $1^{\circ}$. The samples were scanned between $5^{\circ}$ and $75^{\circ}$ 2 theta with a X'Celerator detector.

Attenuated total reflectance (ATR) Fourier Transformation-Infrared (FT-IR) spectra were recorded in the mid-region on a Bruker Tensor 27 FT-IR spectrometer between 600 and $4000 \mathrm{~cm}^{-}$ ${ }^{1}$ with a resolution of $4 \mathrm{~cm}^{-1}$ by transmittance on small amounts of powder. Spectra were background corrected and scaled to the maximum of $\mathrm{Si}-\mathrm{O}$ bounds to ease comparison. To separate the wavenumbers corresponding to the different Si bounds from 600 to $1200 \mathrm{~cm}^{-1}$, the second derivative of FT-IR spectra was used to identify the different bands as previously reported by Gionis et al. (2006). "Hydrated" silica fume (silica fume stored in water and freeze dried under the same conditions as M-S-H), synthetic talc, natural antigorite and sepiolite as detailed above were used as references.

In addition to FT-IR, ${ }^{29} \mathrm{Si}$ MAS NMR measurements were performed on few selected samples. The ${ }^{29}$ Si MAS NMR experiments were carried out on a Bruker Avance III NMR spectrometer using a $7 \mathrm{~mm} \mathrm{CP} / \mathrm{MAS}$ probe at $79.5 \mathrm{MHz}$ and applying the following parameters: $4500 \mathrm{~Hz}$ sample rotation rate, min of 3072 scans or more, $90^{\circ} 1 \mathrm{H}$ pulse of $7.5 \mu \mathrm{s}, 20 \mathrm{~s}$ relaxation delays, RF field strength of $33.3 \mathrm{kHz}$ during SPINAL64 proton decoupling. The ${ }^{29} \mathrm{Si}$ chemical shifts NMR spectra were referenced to the Aldrich external sample of tetramethylsilane (TMS) with a ${ }^{29} \mathrm{Si}$ chemical shift at $-2.3 \mathrm{ppm}$. The observed ${ }^{29} \mathrm{Si}$ resonances were analysed using the $\mathrm{Q}^{\mathrm{n}}$ classification, where a Si tetrahedron is connected to $\mathrm{n}$ Si tetrahedra with $\mathrm{n}$ varying from 0 to 4 . The quantification was performed by non-linear least-square fits using the software "DMFIT" 
developed by Massiot et al. (2002) with a linear combination of Gaussian and Lorentzian functions where $\eta$ was fixed $\left(\eta \mathrm{G}+(1-\eta) L\right.$ with $\mathrm{G}=$ Gaussian, $\mathrm{L}=$ Lorentzian). The $\mathrm{Q}^{1}$ and $\mathrm{Q}^{2}$ environments were deconvoluted using mainly Lorentzian $(\eta=0-0.1)$ while the $Q^{3}$ environment was deconvoluted with Gaussian $(\eta=0.8-1.0)$.

Silica fume was quantified taking into account the shift at $-100.9 \mathrm{ppm}\left((\mathrm{SiO})_{3} \mathrm{Si}-\mathrm{OH}\right.$ from the surface of the amorphous silica (d'Espinose de Lacaillerie et al., 1995; Nied et al., 2016)) and the $\mathrm{Q}^{4}$ shift at -110 ppm. However, the relaxation time $\mathrm{T}_{1}$ of silica fume can be very long and it could be that the amount of silica fume was underestimated.

After quantification of brucite by TGA, and amorphous silica by ${ }^{29} \mathrm{Si}$ MAS NMR, the experimental molar $\mathrm{Mg} / \mathrm{Si}$ ratios in $\mathrm{M}-\mathrm{S}-\mathrm{H}$ were calculated by mass balance including the IC results following the equation (2):

$$
\frac{\mathrm{Mg}}{\mathrm{Si}}=\frac{n_{\text {init }}(\mathrm{MgO})-n_{\text {tga }}(\text { brucite })-n_{I C}([\mathrm{Mg}])}{n_{\text {init }}\left(\mathrm{SiO}_{2}\right)-n_{n m r}(\text { unreact. silica })-n_{I C}([\mathrm{Si}])}
$$

$n_{\text {init }}(\mathrm{MgO})=$ mole of magnesium oxide initially added

$n_{\text {tga }}$ (brucite) $=$ mole of magnesium hydroxide in the sample quantified by thermogravimetric analysis

$n_{I C}([M g])=$ mole of dissolved magnesium in solution quantified by ion chromatography

$n_{\text {init }}\left(\mathrm{SiO}_{2}\right)=$ mole of silica fume initially added

$n_{n m r}($ unreact. silica $)=$ mole of amorphous silica in the sample quantified by ${ }^{29}$ Si MAS NMR

$n_{I C}([S i])=$ mole of dissolved silicon in solution quantified by ion chromatography

For those samples not analyzed by ${ }^{29} \mathrm{Si}$ MAS NMR, the absence of unreacted silica in the samples was assessed by the nonexistence of FT-IR bands at 1090 and $1035 \mathrm{~cm}^{-1}$ characteristic for amorphous silica and based on the low silicon concentration $(<0.3 \mathrm{mM})$ in the aqueous solution. 


\subsection{Saturation indices and thermodynamic data}

From the measured concentrations in solution and the $\mathrm{pH}$ values, the activities of dissolved species were calculated using the geochemical software GEMS v3.3 (Kulik et al., 2013) together with the PSI database (Thoenen et al., 2014). The activity of a species $\mathrm{i},\{\mathrm{i}\}$, is calculated from the measured concentrations considering the formation of different aqueous complexes; $\{i\}=$ $\gamma_{i} \cdot m_{i}$, where $\gamma_{i}$ is the activity coefficient and $m_{i}$ is the concentration in $m o l / k g H_{2} \mathrm{O}$. The activity coefficients of the aqueous species $\gamma_{\mathrm{i}}$ were computed with the built-in extended Debye-Hückel equation with common ion-size parameter $a_{i}=3.67 \AA$ for $\mathrm{KOH}$ solutions and common third parameter $b_{y}$ according to the equation (3):

$$
\log \gamma_{i}=\frac{-A_{y} z_{i}^{2} \sqrt{I}}{1+B_{y} a_{i} \sqrt{I}}+b_{y} I
$$

where $\mathrm{z}_{i}$ denotes the charge of species $i$, I the effective molal ionic strength, $b_{y}$ is a semi-empirical parameter $\left(\sim 0.123\right.$ for $\mathrm{KOH}$ electrolyte at $\left.25^{\circ} \mathrm{C}\right)$, and $\mathrm{A}_{y}$ and $\mathrm{B}_{y}$ are $\mathrm{P}, \mathrm{T}$-dependent coefficients. This activity correction is applicable up to $\sim 1 \mathrm{M}$ ionic strength (Merkel and Planer-Friedrich, 2008).

The saturation indices (SI) of the different solids were calculated from the ion activity product (IAP) based on the measured concentrations in solution according to the equation (4):

$$
S I=\log \frac{\mathrm{IAP}}{\mathrm{Kso}}
$$

$I A P=$ ion activity product

Kso $=$ theoretical solubility product of the solid 
A saturation index $(\mathrm{SI})<0$ indicates that the solution is undersaturated and the respective solid should not form or will dissolve if present, SI $>0$ means that the solution is oversatured and the formation of the respective solid is possible. In our case, knowledge of the SI of the solution with respect to brucite or amorphous silica was used to follow the kinetics of dissolution during the formation of M-S-H. The solubility product of amorphous silica used equals to $10^{-2.90}$ for the reaction of $\mathrm{SiO}_{2, \text { solid }}$ to $\mathrm{Si}(\mathrm{OH})_{4, \text { aq }}$ corresponding to the measured silicon concentrations at $20^{\circ} \mathrm{C}$. Similarly, solubility products of $10^{-2.63}$ and $10^{-2.57}$ were calculated for 50 and $70^{\circ} \mathrm{C}$ from the experimental data.

The solubility products of $\mathrm{M}-\mathrm{S}-\mathrm{H}$ were calculated with respect to two end members with compositions of $\mathrm{M}_{0.78} \mathrm{~S}_{1} \mathrm{H}_{1.48}\left(\mathrm{M}=\mathrm{MgO}, \mathrm{S}=\mathrm{SiO}_{2}, \mathrm{H}=\mathrm{H}_{2} \mathrm{O}\right)$ and $\mathrm{M}_{1.30} \mathrm{~S}_{1} \mathrm{H}_{1.80}$. The composition from $0.78<\mathrm{Mg} / \mathrm{Si}<1.30$ were obtained by assuming an ideal solid solution between the two end members with $\mathrm{Mg} / \mathrm{Si}=0.78$ and $\mathrm{Mg} / \mathrm{Si}=1.30$ as suggested by Nied et al. (2016).

From the solubility products calculated at different temperatures, the Gibbs free energy of reaction, $\Delta_{\mathrm{r}} \mathrm{G}^{\circ}$, and the Gibbs free energy of formation, $\Delta_{\mathrm{f}} \mathrm{G}^{\circ}$, at $25^{\circ} \mathrm{C}$ can be obtained according to equations (5) and (6):

$$
\begin{gathered}
\Delta_{r} G^{\circ}=-\mathrm{RT} \ln K=\sum_{i} v_{i} \Delta_{f} G_{T}^{\circ} \\
\Delta_{a} G_{T}^{\circ}=\Delta_{f} G^{\circ} T_{0}-S^{\circ} T_{0}\left(T-T_{0}\right)-\int_{T_{0}}^{T} \int_{T_{0}}^{T} \frac{C^{\circ} p}{T} d T d T \cong \Delta_{f} G^{\circ} T_{0}-S_{T_{0}}^{\circ}\left(T-T_{0}\right)-a\left(T \ln \frac{T}{T_{0}}-T-\right. \\
\left.T_{0}\right)-b \frac{\left(T-T_{0}\right)^{2}}{2}-c \frac{\left(T-T_{0}\right)^{2}}{2 T \cdot T_{0}{ }^{2}}-d \frac{2\left(\sqrt{T}-\sqrt{T_{0}}\right)^{2}}{\sqrt{T_{0}}}
\end{gathered}
$$

where $v_{i}$ are the stoichiometric reaction coefficients, $\mathrm{R}=8.31451 \mathrm{~J} / \mathrm{mol} / \mathrm{K}$ and $\mathrm{T}$ is the temperature in $\mathrm{K}$. The apparent Gibbs free energy of formation, $\Delta_{\mathrm{a}} \mathrm{G}^{\circ} \mathrm{T}$, refers to the free energies 
of the elements at $298 \mathrm{~K}$. A more detailed description of the derivation of the dependence of the Gibbs free energy on temperature is given in Anderson and Crerar (1993) and Kulik (2002). In the present paper the empirical coefficients a, b, c, and $\mathrm{d}$ of the heat capacity, $\mathrm{C}_{\mathrm{p}}^{\circ}$ $\left(\mathrm{C}^{0} \mathrm{p}=\mathrm{a}+\mathrm{bT}+\mathrm{cT}^{-2}+\mathrm{dT}^{-1 / 2}\right)$ were calculated from the coefficients of talc, chrysotile and antigorite given in Holland and Powell (1998) and adjusted for the water content of the M-S-H phases. The entropy, $\mathrm{S}^{\circ}$, was calculated in the same way from talc, chrysotile and antigorite and water.

\section{Results and Discussions}

\subsection{Kinetics of $\mathrm{M}-\mathrm{S}-\mathrm{H}$ formation at $20^{\circ} \mathrm{C}$}

\subsubsection{Up to 3 months}

To understand the M-S-H formation process, the reaction of samples with initial $\mathrm{Mg} / \mathrm{Si}=0.8$ and 1.2 ratio was followed from 1 day to 3 months. The $\mathrm{MgO}$ reacted completely within the first day (absence of reflections at 36.9, 42.9, 62.3 2theta (Li et al., 2014)) to $\mathrm{Mg}(\mathrm{OH})_{2}$ (brucite) and M-S$\mathrm{H}$, leaving some unreacted silica as shown in Figure 1. 


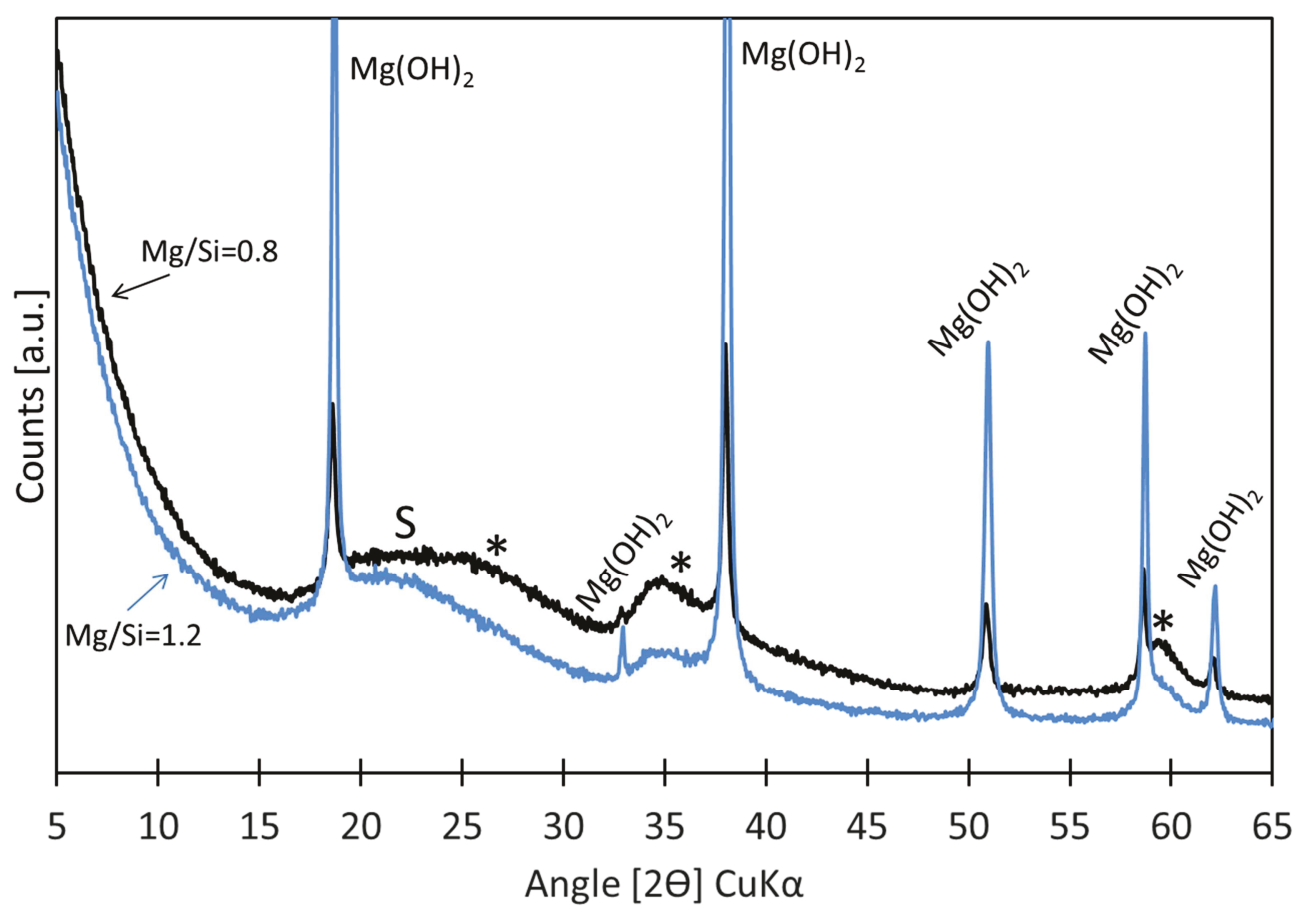

Figure 1: XRD patterns of M-S-H 0.8 and 1.2 after 1 day of curing at $20^{\circ} \mathrm{C}\left({ }^{*}=M-S-H, S=\right.$ silica fume $)$.

The dissolved concentrations and $\mathrm{pH}$ values measured for the two samples are displayed in Figure $2 \mathrm{a}$ and $2 \mathrm{~b}$. The magnesium concentrations decreased between 1 and 3 days to $\sim 0.1 \mathrm{mM}$. Saturation indices (SI) with respect to brucite (Figure $2 \mathrm{~d}$ ) showed values close to saturation (SI $\approx$ 0) during the first day, consistent with the observed precipitation of brucite. However, after 3 days the solution became undersaturated with respect to brucite (Figure 2d) although brucite was observed. The silicon concentrations increased slowly and reached $\sim 1.3 \mathrm{mM}$ (Figure $2 \mathrm{a}$ and $2 \mathrm{~b}$ ), i.e. saturation with respect to silica, within 3 days (Figure 2c).

From 3 to 91 days little change was observed in the solutions. At $\mathrm{Mg} / \mathrm{Si}=0.8$ and 1.2 , representing low and high ratios, similar concentrations were measured: a relatively high concentration of silicon in equilibrium with amorphous silica (Gunnarsson and Arnórsson, 2000) (Figure $2 \mathrm{a}$ and $2 \mathrm{~b}$ ). Low concentrations of magnesium (Figure $2 \mathrm{a}$ and $2 \mathrm{~b}$ ) and $\mathrm{pH}$ values between 9.3-9.6 were observed (Figure 3) while M-S-H phases formed slowly. The magnesium 
concentration increased slightly from 2 to 3 months. Up to day 91, the solutions were still undersaturated with respect to brucite (as detailed in Figure 2d) although XRD and TGA data indicate that brucite was present in the solid phase (as detailed further below in section 3.1.2.3). This persistence of brucite indicates a kinetic hindrance of brucite dissolution which is discussed in section 3.1.2.3. and probably limits the rate of $\mathrm{M}-\mathrm{S}-\mathrm{H}$ formation.
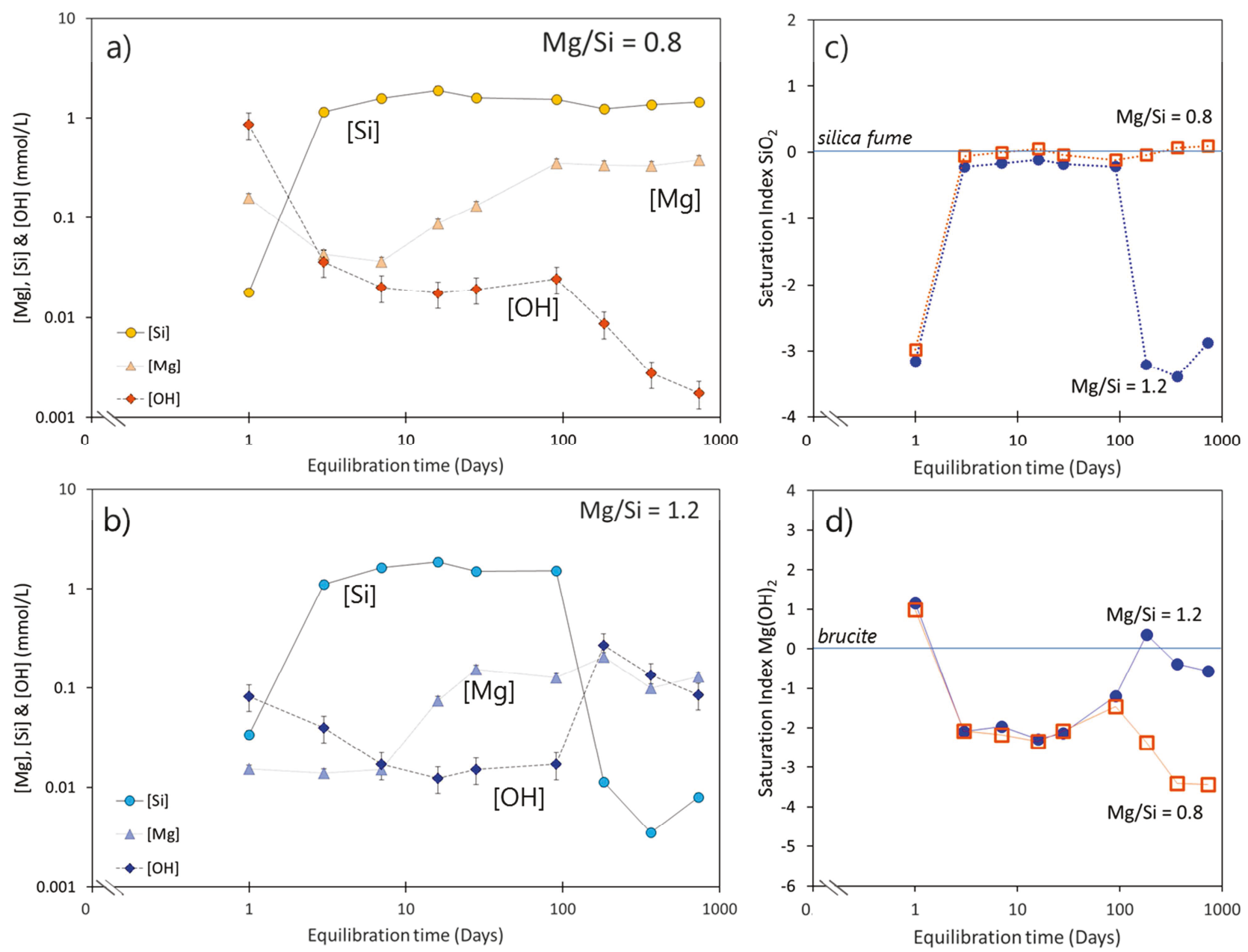

Figure 2: Dissolved ions in aqueous phase at equilibrium with $\mathrm{MgO}$ and $\mathrm{SiO}_{2}$ during the formation of $\mathrm{M}-\mathrm{S}$ - $\mathrm{H}$ a) $\mathrm{Mg} / \mathrm{Si}=0.8$ and b) $\mathrm{Mg} / \mathrm{Si}=1.2$. Calculated saturation indices (SI) of silica fume (c) and calculated SI of brucite (d) for samples $\mathrm{Mg} / \mathrm{Si}=0.8$ and 1.2 . 


\subsubsection{3 months to 2 years}

\subsubsection{Aqueous phase}

Only after 91 days, the pore solutions of the samples $\mathrm{Mg} / \mathrm{Si}=0.8$ and $\mathrm{Mg} / \mathrm{Si}=1.2$ started to differentiate. The equilibrium for $\mathrm{Mg} / \mathrm{Si}=0.8$ seems to be approximately reached within 91 days and the silicon and magnesium concentrations remained stable thereafter (Figure 2a) while $\mathrm{pH}$ decreased somewhat from 9.6 to 8.4 after 730 days (Figure 3). In contrast, in the sample with $\mathrm{Mg} / \mathrm{Si}=1.2$ the silicon concentration dropped as the silica initially present had reacted (see section 3.1.2.2.) and the $\mathrm{pH}$ values increased from 9.4 to 10.3 (Figure 3). The solution became undersaturated with respect to silica fume and saturated with respect to brucite (Figure $2 \mathrm{c}$ and 2d).

After the first 91 days (3 months), all $\mathrm{pH}$ values were within a narrow range of 9.3-9.6 independently of the total $\mathrm{Mg} / \mathrm{Si}$ ratio which varied from 0.8 to 1.6 (Figure 3). Also the concentrations of magnesium and silicon were similar as they were determined by the presence of brucite and amorphous silica independently of the initial $\mathrm{Mg} / \mathrm{Si}$ ratio (see Appendix). Only after 182 days (6 months) and longer, clear differences in the $\mathrm{pH}$ values were observed. The samples with higher initial $\mathrm{Mg} / \mathrm{Si}$ ratio $(\mathrm{Mg} / \mathrm{Si} \geq 1)$ showed an increase of the $\mathrm{pH}$ values, while $\mathrm{pH}$ decreased at lower $\mathrm{Mg} / \mathrm{Si}$ ratio. After 365 days and longer, the $\mathrm{pH}$ increased with the initial $\mathrm{Mg} / \mathrm{Si}$ ratio ranging between 0.8 and 1.2 and was constant at $\mathrm{Mg} / \mathrm{Si}$ ratio higher than 1.3 with $\mathrm{pH}$ values from 10.3 to 10.5 . The $\mathrm{pH}$ of the solution in equilibrium with sample M-S-H 1.0 was at all times between $\sim 9.5$ to 9.2 indicating little change at $\mathrm{Mg} / \mathrm{Si}=1.0$. 


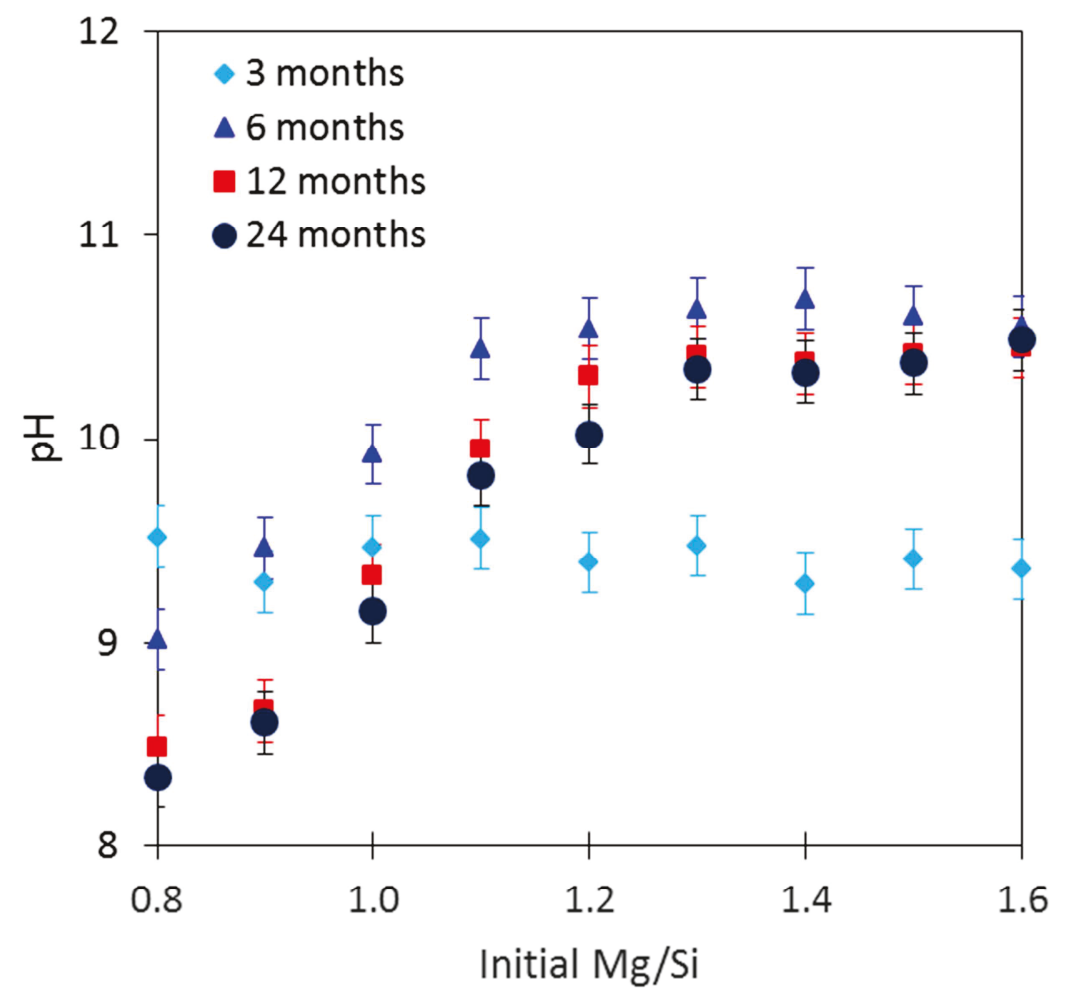

Figure 3: Evolution of $\mathrm{pH}$ values at $20^{\circ} \mathrm{C}$ over time as function of initial Mg/Si ratio (0.8-1.6).

\subsubsection{Unreacted silica}

The silicon concentrations are plotted versus $\mathrm{pH}$ in Figure 4. The dissolved silicon concentrations measured after 3 months were close to the solubility of the amorphous silica which indicates that unreacted silica could be present in the samples. The presence of unreacted silica fume is confirmed by ${ }^{29} \mathrm{Si}$ MAS NMR (Figure 5) and FT-IR (Figure 6). Silica was observed after 3 months in all samples, independently of the initial $\mathrm{Mg} / \mathrm{Si}$ ratio. 


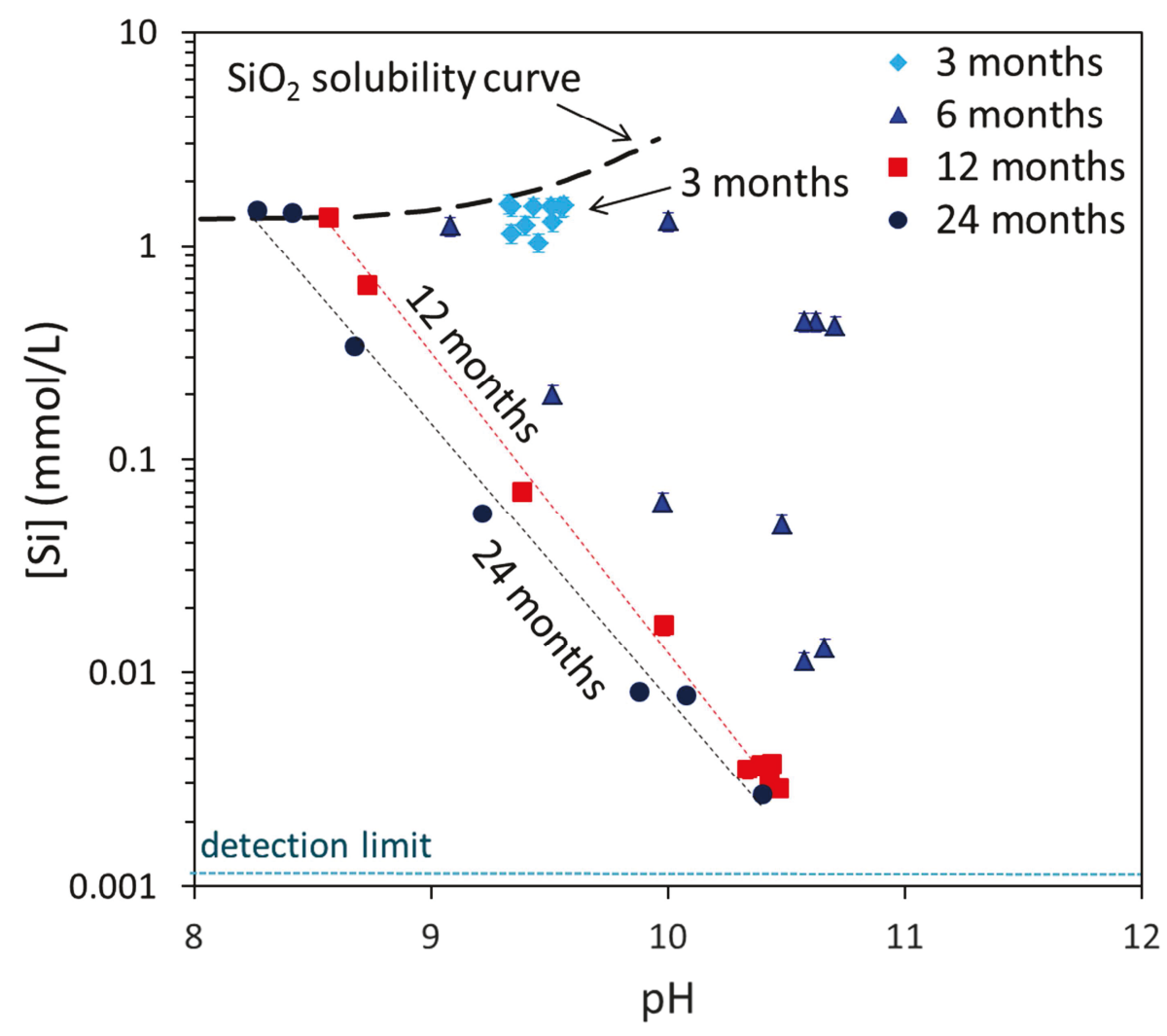

Figure 4: Changes of silicon concentrations with $\mathrm{pH}\left(\mathrm{pH}\right.$ at $\left.20^{\circ} \mathrm{C}\right)$ and time. Dotted lines have been added as guide line.

In ${ }^{29} \mathrm{Si}$ MAS NMR spectra unreacted silica was observed by a main resonance at $-110 \mathrm{ppm}\left(\mathrm{Q}^{4}\right)$

(Figure 5), and by a minor resonance at $-100.9 \mathrm{ppm}$ related to hydrated silanol groups $\mathrm{Q}^{3}(-\mathrm{OH})$ (d'Espinose de Lacaillerie et al., 1995; Nied et al., 2016). The amount of unreacted silica was quantified based on the intensity of the resonances $\mathrm{Q}^{4}$ at -110 and $\mathrm{Q}^{3}(-\mathrm{OH})$ at $-100.9 \mathrm{ppm}$ as shown in Figure 5 following the procedure outlined by Nied et al. (2016). In the samples with initial $\mathrm{Mg} / \mathrm{Si}$ ratio of 0.8 and 1.4 approximately $16 \%$ and $6 \%$ of unreacted silica was detected after 3 months. After 1 year $\simeq 4 \%$ of unreacted silica was observed in the sample with initial $\mathrm{Mg} / \mathrm{Si}=0.8$ and none for $\mathrm{Mg} / \mathrm{Si}=1.4$ (Table 2 and Figure 8), indicating that most of amorphous silica reacted within 12 months to form more M-S-H. 
Unreacted silica can also be identified by FT-IR based on the bands at $\sim 1090 \mathrm{~cm}^{-1}, 1035 \mathrm{~cm}^{-1}$ and $803 \mathrm{~cm}^{-1}$ as shown in Figure 6. As already detailed by Nied et al. (2016), $\mathrm{Q}^{2}$ and $\mathrm{Q}^{3}$ silica species present in M-S-H show vibrations at $870-920 \mathrm{~cm}^{-1}$ and $950-1150 \mathrm{~cm}^{-1}$ as indicated in Figure 6 by the grey shaded regions. The second derivative can be used to identify the characteristic peak positions at $985-1095 \mathrm{~cm}^{-1}$ more clearly. The FT-IR data confirm the presence of unreacted silica by the shoulder at $1035 \mathrm{~cm}^{-1}$ in all samples after 3 months and to a lower extent also after 6 months. After 1 year the presence of residual silica was only observed for $\mathrm{Mg} / \mathrm{Si} \leq 0.8$, in agreement with the ${ }^{29} \mathrm{Si}$ MAS NMR data. Although FT-IR can indicate only qualitatively the presence of amorphous silica, in combination with high silicon concentrations, which signpost saturation with respect to amorphous silica (see values in Appendix), the presence of amorphous silica can be shown for those samples where no ${ }^{29} \mathrm{Si}$ MAS NMR data could be measured.
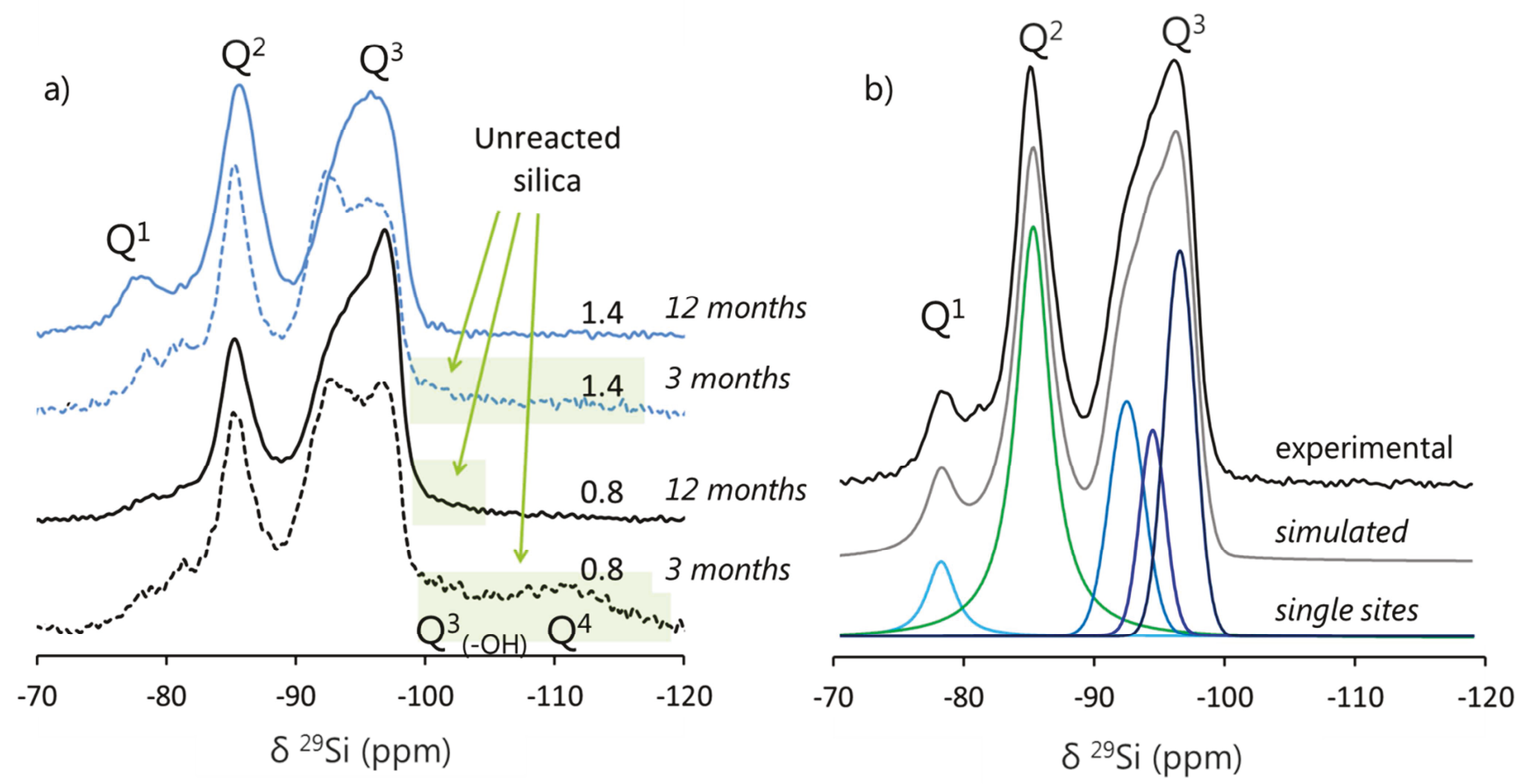

Figure 5: a) ${ }^{29}$ Si MAS NMR spectra with assignments of single sites of $M-S$-H samples (Mg/Si=0.8 and 1.4) after 3 and 12 months, the shaded regions assign unreacted silica species, b) example of the deconvolution (sample $\mathrm{Mg} / \mathrm{Si}=1.0$, after 12 months) of the indicated single sites listed in Table 2. 
Table 2 : Relative intensities of different silicon sites obtained from the deconvolution of the ${ }^{29}$ Si MAS NMR spectra $\left(\delta^{29}\right.$ Si in ppm $\left.\pm 0.3 \mathrm{ppm}\right)$.

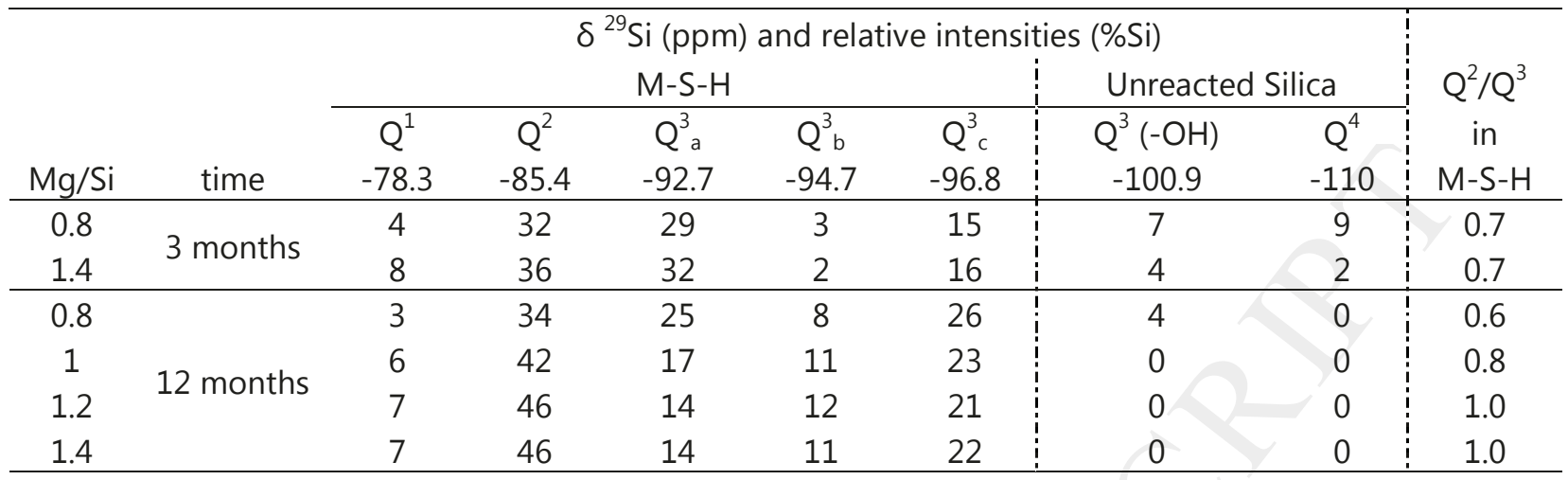

Error $= \pm 2.5$ of absolute amounts of (\%Si)

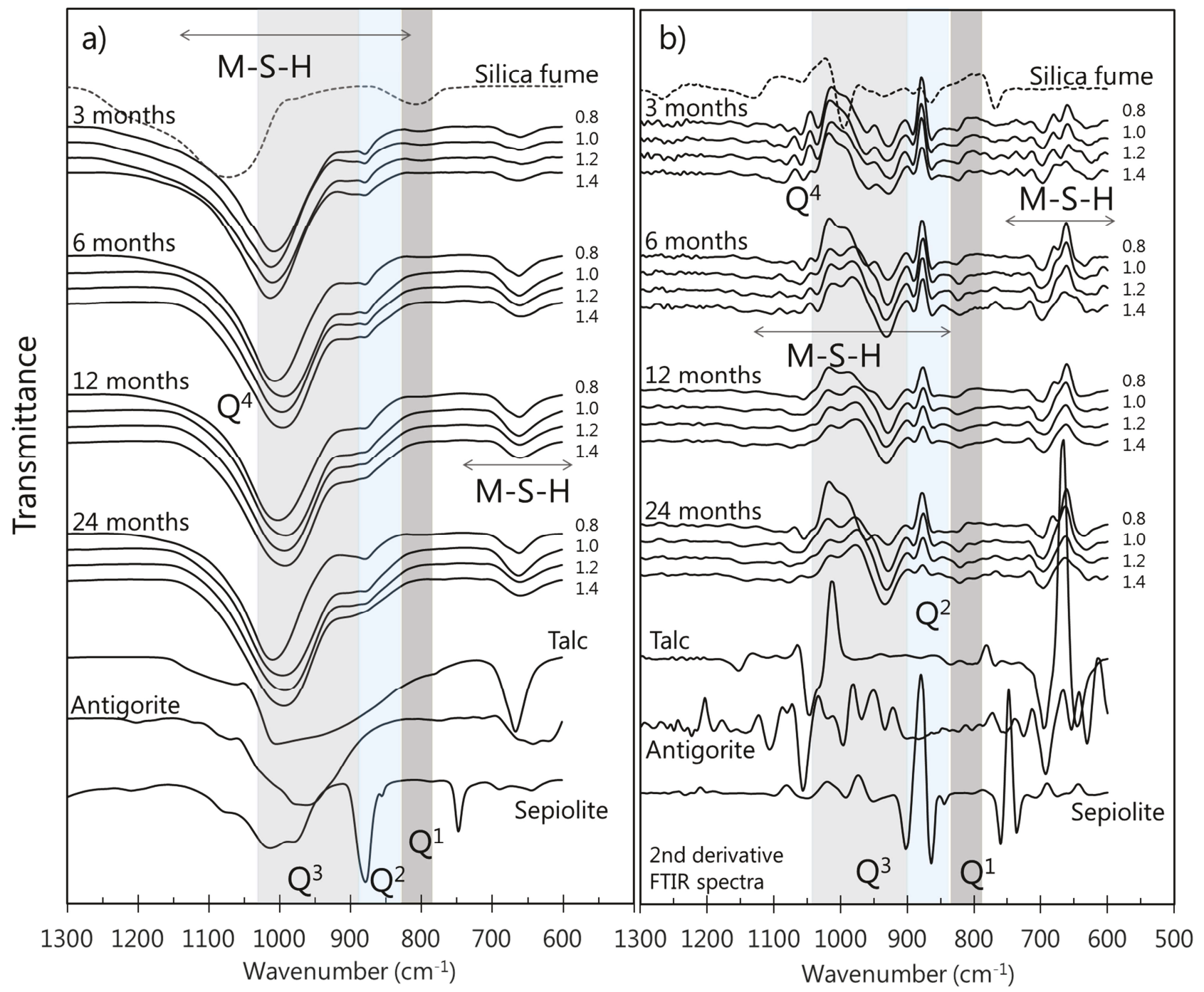

Figure $6:$ a) FT-IR spectra and b) second derivatives of the FT-IR spectra of M-S-H samples $\left(20^{\circ} \mathrm{C}\right)$ with $\mathrm{Mg} / \mathrm{Si}$ of $0.8,1.0,1.2,1.4$. Only the regions characteristic for silica are shown. The shaded areas show characteristic 
regions for $Q^{1}, Q^{2}, Q^{3}$ and $Q^{4}$. Measured spectra of silica fume, talc, antigorite and sepiolite are shown for comparison.

\subsubsection{Reaction of brucite}

The thermogravimetric analyses of the solid phases confirm that brucite dissolution and M-S-H formation occurred only slowly as shown in Figure 7a. After 3 months of equilibration thermogravimetric analysis indicates that brucite was still present in all samples, as visible by a well-defined weight loss in the shaded temperature range centered at $410^{\circ} \mathrm{C}$. XRD measurements (Figure 7b) confirm the presence of brucite (reflections peaks at 18.6, 32.7, 38.0, 50.9, 58.7, 62.0 2theta (Brew and Glasser, 2005b; Zhang et al., 2011) in the XRD patterns (Figure 7b)) together with unreacted silica (broad hump at $21-24^{\circ}$ 2theta) as previously observed by FT-IR and ${ }^{29} \mathrm{Si}$ MAS NMR.

The thermogravimetric data (Figure 7a) show already after 3 months the two water loss regions typical for M-S-H (Mitsuda and Taguchi, 1977; Nied et al., 2016; Zhang et al., 2011). The first weight loss between $30^{\circ} \mathrm{C}$ and $250^{\circ} \mathrm{C}$ is due to poorly bound water in the interlayer or on the surface. The second weight loss between $250^{\circ} \mathrm{C}$ and $800^{\circ} \mathrm{C}$, overlapping with the "brucite weight loss", is attributed to the dehydroxylation of magnesium or silanol hydroxyl groups (Nied et al., 2016; Szczerba et al., 2013).

After 2 years the characteristic XRD humps of M-S-H are better defined than after 1 day (Figure 1) or 3 months (Figure $7 \mathrm{~b})$ of reaction, while much less $(\mathrm{Mg} / \mathrm{Si}=1.4)$ or no brucite $(\mathrm{Mg} / \mathrm{Si}=0.8)$ was present. 

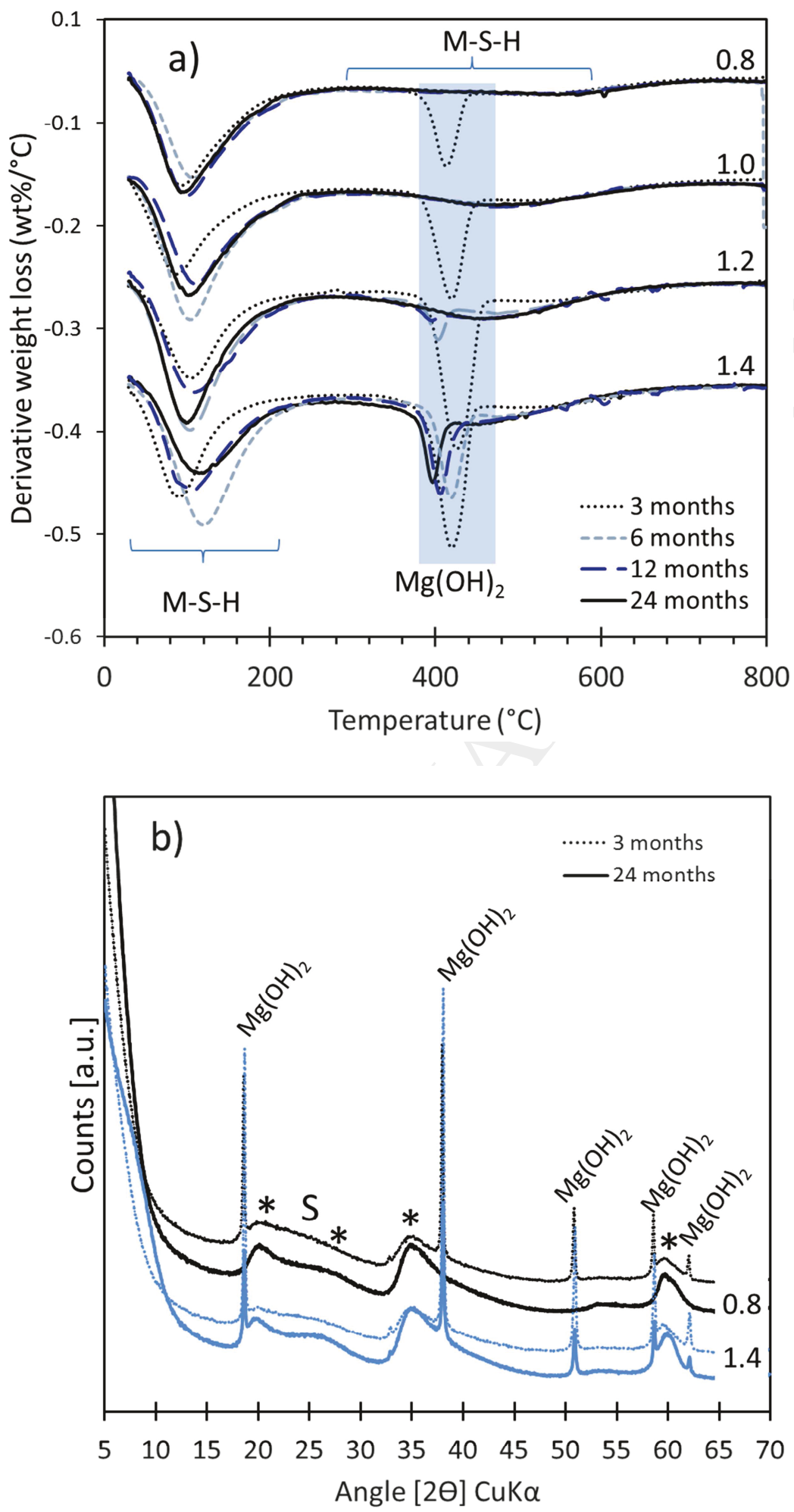

Figure 7: a) Derivative of thermogravimetric analyses of $M-S$ - $H$ samples synthetized at $20^{\circ} \mathrm{C}, \mathrm{Mg} / \mathrm{Si}=0.8,1.0,1.2$, 1.4 aged of 3 months (dotted lines) 6 months (grey dashed lines), 1 year (blue large dashed lines) and 2 years (solid lines), grey shaded region = water loss of brucite. b)XRD patterns of $M-S-H$ samples synthetized at $20^{\circ} \mathrm{C}$, $\mathrm{Mg} / \mathrm{Si}=0.8,1.4$ aged of 3 months (dotted lines) and 2 years (solid lines) ${ }^{*}=M-S-H, S=$ silica fume). 
Figure 8 a summarizes the amount of brucite contained in the samples as a function of time. The presence of brucite after 3 months in all samples is consistent with the similar magnesium concentrations in all solutions. The amount of brucite increased with the initial $\mathrm{MgO}$ content. While after 3 months brucite was observed in all samples, brucite was only present for $\mathrm{Mg} / \mathrm{Si}>1$ after 6 months and for $\mathrm{Mg} / \mathrm{Si}>1.2$ after 2 years, indicating that all the magnesium is in $\mathrm{M}-\mathrm{S}-\mathrm{H}$ phases after long reaction times and that a maximum $\mathrm{Mg} / \mathrm{Si}$ of $\approx 1.3$ can be reached at room temperature.
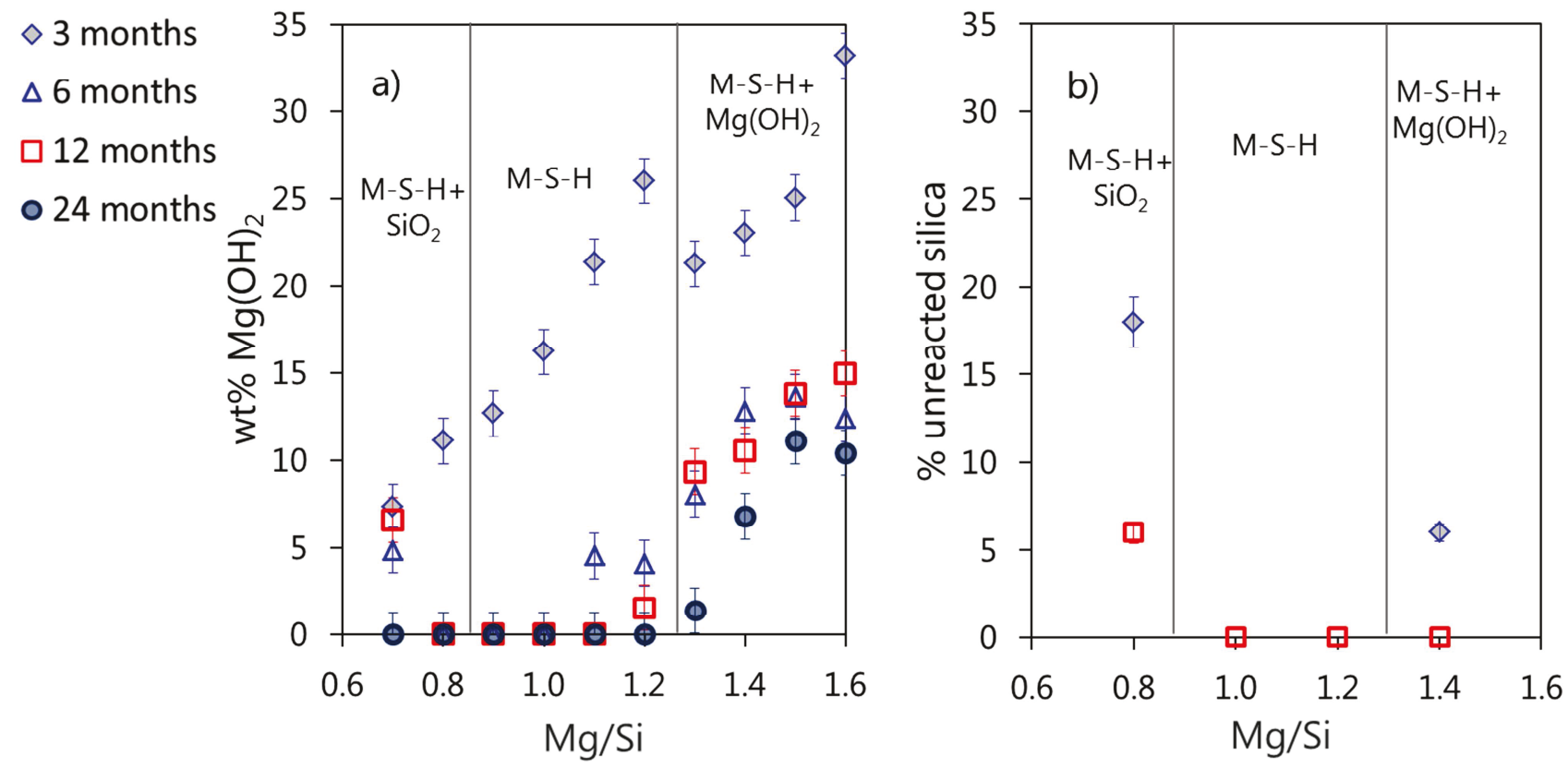

Figure 8 : Amount of a) brucite (from TGA) (wt\% of brucite normalized to $100 \mathrm{~g}$ dry mass) and b) unreacted silica (from ${ }^{29} \mathrm{Si} M A S \mathrm{NMR}$ ) per total of silica in samples cured at $20^{\circ} \mathrm{C}$ as a function of the initial $\mathrm{Mg} / \mathrm{Si}$ and time. Vertical lines separate the area where i) silica $+M-S-H$, ii) $M-S-H$ only and iii) $M-S-H+$ brucite are present after long reaction times.

If brucite was present, its amount increased nearly linearly with the total $\mathrm{Mg} / \mathrm{Si}$ (Figure 8a). Even though some brucite was still present, the amount was very low compared to the initial amount of magnesium as indicated in Table 3 confirming the dissolution of brucite and the presence of mainly M-S-H after 1 year and longer. 
Table 3: Theoretical and experimental measured brucite content in $w t \%$.

\begin{tabular}{ccccc}
\hline total $\mathrm{Mg} / \mathrm{Si}$ & 0.8 & 1 & 1.2 & 1.4 \\
\hline $\begin{array}{c}\text { theoretical maximum brucite content }^{*} \\
\text { experimental brucite }\end{array}$ & 51 & 58 & 65 & 70 \\
1 year at $20^{\circ} \mathrm{C}$ & & & & \\
2 years at $20^{\circ} \mathrm{C}$ & $<0.1$ & $<0.1$ & $1.5 \pm 1$ & $10.6 \pm 1$ \\
1 year at $50^{\circ} \mathrm{C}$ & $<0.1$ & $<0.1$ & $<0.1$ & $6.8 \pm 1$ \\
1 year at $70^{\circ} \mathrm{C}$ & $<0.1$ & $<0.1$ & $0.2 \pm 0.2$ & $7.2 \pm 1$ \\
& $<0.1$ & $<0.1$ & $<0.1$ & $6.2 \pm 1$ \\
\hline
\end{tabular}

* Theoretical maximum brucite content: amount of brucite which could form from MgO considering the total mass of the solids (brucite + amorphous silica)

$<0.1$ : not detected by TGA

It has been reported that the reaction of $\mathrm{MgO}$ to brucite is strongly retarded by the presence of dissolved silicon (Salomão and Pandolfelli, 2008). Based on that it may be tentatively concluded that also the dissolution of brucite is retarded by the presence of silicon in solution. In the absence of silica, the solutions equilibrated fast with brucite and measured magnesium concentrations and $\mathrm{pH}$ values were in the range of the calculated brucite solubility as shown in Figure 9a. In contrast, samples with 1 or $1.5 \mathrm{mM}$ silicon in solution had lower $\mathrm{pH}$ values and remained clearly under saturated with respect to brucite. A plot of saturation indices of brucite versus the measured silica concentrations (Figure 9b) shows a strong undersaturation with respect to brucite at silicon concentrations of $1 \mathrm{mM}$ or higher. This dependence confirms a kinetic hindrance of brucite dissolution at high silicon concentrations (>1mM). 

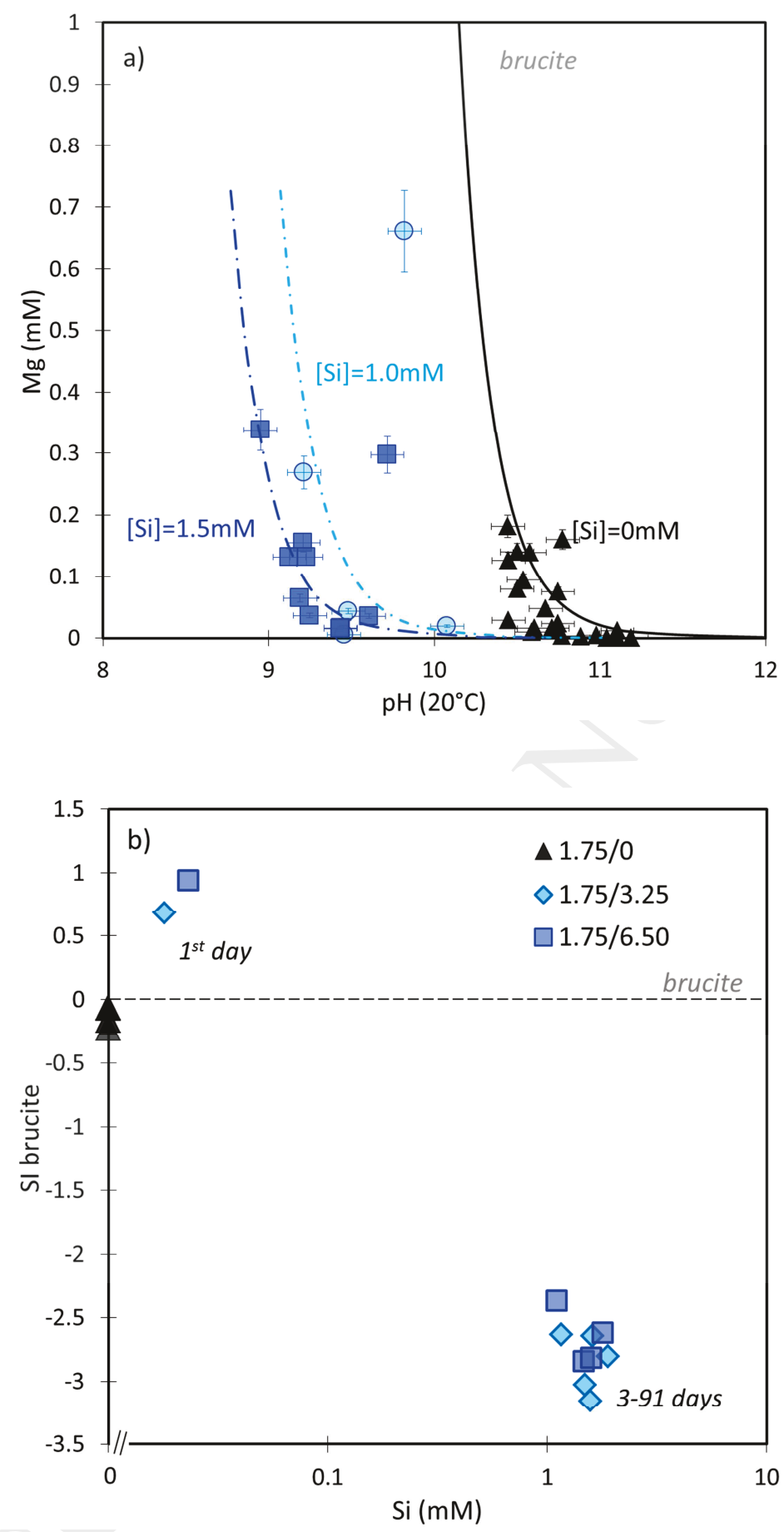

Figure 9: a) Concentration of magnesium measured for $\mathrm{MgO}$ only and for $\mathrm{MgO} / \mathrm{SiO}_{2}$ with weight ratio $=1.75 \mathrm{~g} / \mathrm{Og}$, $1.75 \mathrm{~g} / 3.25 \mathrm{~g}$ and $1.75 \mathrm{~g} / 6.50 \mathrm{~g}$ between 1 and 28 days plotted as a function of $\mathrm{pH}$ and compared to solubility of brucite as calculated with GEMS. b) Calculated saturation indices of brucite as a function of the silicon concentrations.

At later ages when the amorphous silica is dissolved, silicon concentrations are lowered, such that the dissolution of brucite is no longer hindered and saturation with respect to brucite is 
reached again as shown in Figure 2. However, even under these conditions, the dissolution of brucite is expected to be slow due to the high $\mathrm{pH}$ values and low magnesium concentrations which limits magnesium uptake in M-S-H.

\subsection{Rearrangement of M-S-H structure with time}

\subsubsection{Structure of the transitional product}

${ }^{29} \mathrm{Si}$ MAS NMR spectra in Figure 5 show the presence of a small quantity of $\mathrm{Q}^{1}$, some $\mathrm{Q}^{2}$ and mainly $\mathrm{Q}^{3}$ silica sites indicating the predominance of sheets of silica in the M-S-H phases. The deconvolution of the $\mathrm{Q}^{3}$ silica resonance exhibits 3 different ${ }^{29} \mathrm{Si}$ chemical shifts indicating 3 slightly differing chemical environments, as previously discussed in Nied et al. (2016) and Roosz et al. (2015). The ${ }^{29} \mathrm{Si}$ NMR chemical shifts of the $\mathrm{Q}^{3}{ }_{\mathrm{a}}, \mathrm{Q}^{3}{ }_{\mathrm{b}}$, and $\mathrm{Q}^{3}{ }_{\mathrm{c}}$ signals at -93 , -95 , and -97 ppm (Figure 5b and Table 2) correspond to the shifts observed for serpentine group minerals (MacKenzie and Meinhold, 1994; Nied et al., 2016) and for talc (Chabrol et al., 2010; Dumas et al., 2013; Nied et al., 2016; Rhouta et al., 2008; Roosz et al., 2015), respectively. Neglecting the unreacted silica (Table 2), the distribution of silica species in M-S-H 0.8 and M-S-H 1.4 was similar after 3 months, except that the sample with the higher $\mathrm{Mg} / \mathrm{Si}$ ratio contained slightly more $\mathrm{Q}^{1}$ (Table 2). The samples have also a similar $\mathrm{Q}^{2} / \mathrm{Q}^{3}$ ratio of $\sim 0.7$ (details in Table 2 and Figure 10) as well as similar FT-IR spectra (Figure 6), independently of the $\mathrm{Mg} / \mathrm{Si}$ ratio. Also the FT-IR data indicate the presence of a small quantity of $\mathrm{Q}^{1}$ sites, two different $\mathrm{Q}^{2}$ and three different $\mathrm{Q}^{3}$ sites corresponding to the maxima of the second derivatives in Figure $6 \mathrm{~b}$ between 950 and 1020 $\mathrm{cm}^{-1}$. The position of the $\mathrm{Q}^{3}$ c peak at $1016 \mathrm{~cm}^{-1}$ corresponds to the $\mathrm{Q}^{3}$ site of talc. In addition, shoulders at $985 \mathrm{~cm}^{-1}$ and at $957 \mathrm{~cm}^{-1}$ are visible, which could correspond to the $\mathrm{Q}^{3}$ and $\mathrm{Q}^{3} \mathrm{~b}$ sites observed by ${ }^{29}$ Si MAS NMR. This indicates the presence of a "transitional" M-S-H phase after 3 months with a structure independently of the total $\mathrm{Mg} / \mathrm{Si}$ ratio as the transitional $\mathrm{M}-\mathrm{S}-\mathrm{H}$ was 
formed due to simultaneous presence of unreacted silica (Table 2) and brucite (Figure 8) and was present as long as silica and/or brucite were fully consumed. The initial formation of such a transitional M-S-H and its persistence up to 3 months is consistent with the constant composition of the pore solution during this time shown in Figure 2a and 2b.

After $\simeq 6$ months these "transitional" $\mathrm{Q}^{3} \mathrm{a}$ and $\mathrm{Q}^{3} \mathrm{~b}$ peaks in the second derivative of FT-IR spectra are replaced by better defined peaks at 1000 and $985 \mathrm{~cm}^{-1}$ corresponding to the bands observed for antigorite. More intense bands of these $\mathrm{Q}^{3}{ }_{\mathrm{a}}$ and $\mathrm{Q}^{3}{ }_{\mathrm{b}}$ are present at high $\mathrm{Mg} / \mathrm{Si}$, as previously observed by Nied et al. (2016).

The position of the Si-O-Si bending band at $\sim 660 \mathrm{~cm}^{-1}$ is influenced by the Si-O-Si angles and by the occupancy of neighboring sites. Well defined, narrow bands as in the case of talc indicate a high degree of symmetry and ordering (Cong and Kirkpatrick, 1996; Yu et al., 1999). The broadness of the M-S-H bands between 600 and $710 \mathrm{~cm}^{-1}$ indicates a low symmetry of the structure which became more ordered with time as narrower bands can be observed in Figure 6a after 12 and 24 months. Similar observations by XRD with better defined humps indicate as well a better crystallinity after 12 and 24 months.

In summary, after 3 months at $20^{\circ} \mathrm{C}$, all samples contained brucite, unreacted silica fume and a "transitional" M-S-H with a low degree of organization and a $\mathrm{Mg} / \mathrm{Si}$ ratio in the range of $0.9-1.1$ (Table 4). This transitional M-S-H is in equilibrium with $\sim 0.2 \mathrm{mM}$ magnesium and $\sim 1.5 \mathrm{mM}$ silicon in all samples (Figure 2) as the presence of amorphous silica buffered the silicon concentrations to $\sim 1.5 \mathrm{mM}$ and the $\mathrm{pH}$ values to $\sim 9.4$. This solution is in equilibrium with M-S$\mathrm{H}$ with $\mathrm{Mg} / \mathrm{Si} \simeq 1.0$ (Figure 3). 
Only after 12 and 24 months M-S-H phases with different $\mathrm{Mg} / \mathrm{Si}$ and thus different structures were identified with $\mathrm{Mg} / \mathrm{Si}$ ratios in the range between 0.8 and 1.3 at $20^{\circ} \mathrm{C}$ as detailed in Table 4 .

Table 4: Experimentally determined composition of $M-S-H$ phases synthesized at 20,50 and $70^{\circ} \mathrm{C}$ by mass balance following the equation (2) (corrected for the amount of brucite quantified by TGA and amorphous silica by ${ }^{29} \mathrm{Si}$ MAS NMR). Total water determined from TGA.

\begin{tabular}{ccccc}
\hline initial $\mathrm{Mg} / \mathrm{Si}$ & 0.8 & 1.0 & 1.2 & 1.4 \\
\hline 3 months $-20^{\circ} \mathrm{C}$ & $\mathrm{M}_{0.89} \mathrm{SH}_{1.46}$ & n.d. & n.d. & $\mathrm{M}_{1.07} \mathrm{SH}_{1.58}$ \\
1 year $-20^{\circ} \mathrm{C}$ & $\mathrm{M}_{0.84} \mathrm{SH}_{1.52}$ & $\mathrm{M}_{1.00} \mathrm{SH}_{1.58}$ & $\mathrm{M}_{1.19} \mathrm{SH}_{1.75}$ & $\mathrm{M}_{1.24} \mathrm{SH}_{1.67}$ \\
2 years $-20^{\circ} \mathrm{C}$ & $\mathrm{M}_{0.83} \mathrm{SH}_{1.63}$ & $\mathrm{M}_{1.00} \mathrm{SH}_{1.70}$ & $\mathrm{M}_{1.20} \mathrm{SH}_{1.89}$ & $\mathrm{M}_{1.29} \mathrm{SH}_{1.64}$ \\
1 month $-50^{\circ} \mathrm{C}$ & $\mathrm{M}_{0.84} \mathrm{SH}_{1.63}$ & n.d. & n.d. & n.d. \\
1 year $-50^{\circ} \mathrm{C}$ & $\mathrm{M}_{0.85} \mathrm{SH}_{1.49}$ & $\mathrm{M}_{1.00} \mathrm{SH}_{1.46}$ & $\mathrm{M}_{1.20} \mathrm{SH}_{1.59}$ & $\mathrm{M}_{1.28} \mathrm{SH}_{1.62}$ \\
1 year $-70^{\circ} \mathrm{C}$ & $\mathrm{M}_{0.86} \mathrm{SH}_{1.56}$ & $\mathrm{M}_{1.00} \mathrm{SH}_{1.70}$ & $\mathrm{M}_{1.20} \mathrm{SH}_{1.81}$ & $\mathrm{M}_{1.30} \mathrm{SH}_{1.66}$ \\
\hline n.d. $=$ not determined & & & & \\
Error \pm 0.1 & & & & \\
\end{tabular}

\subsubsection{Effect of Mg/Si on M-S-H structure}

For the samples aged for 1 year, clear differences were visible in the ${ }^{29}$ Si MAS NMR data as the increase of the $\mathrm{Q}^{2} / \mathrm{Q}^{3}$ ratio at higher $\mathrm{Mg} / \mathrm{Si}$ in the $\mathrm{M}-\mathrm{S}-\mathrm{H}$ (Table 2).

The $\mathrm{Q}^{2} / \mathrm{Q}^{3}$ ratios (total $\mathrm{Q}^{3}=\mathrm{Q}^{3}{ }_{\mathrm{a}}+\mathrm{Q}^{3}{ }_{\mathrm{b}}+\mathrm{Q}^{3} \mathrm{c}$ ) of different samples are shown in Figure $10 \mathrm{a}$ as a function of the experimentally determined $\mathrm{Mg} / \mathrm{Si}$ ratio in $\mathrm{M}-\mathrm{S}-\mathrm{H}$ as detailed in Table 4. A strong increase of the relative fraction of $\mathrm{Q}^{2}$ was observed at high $\mathrm{Mg} / \mathrm{Si}$ (Table 2) indicating a change in the arrangement of the silica in M-S-H.

The total amount of water calculated to be present in $\mathrm{M}-\mathrm{S}-\mathrm{H}$ equilibrated at $30 \%$ relative humidity is detailed in Table 4. The amount of total water bound increased with the $\mathrm{Mg} / \mathrm{Si}$ of the M-S-H as reported previously (Nied et al., 2016). It can be expected that the amount of water present in M-S-H depends on the drying conditions as previously observed for $\mathrm{C}-\mathrm{S}-\mathrm{H}$ gels (Lothenbach and Nonat, 2015; Roosz et al., 2016). TGA analysis allows differentiating between loosely bound water in several layers at the surface and in the interlayer $\left(<250{ }^{\circ} \mathrm{C}\right)$ and 
structurally bound water (monolayer on the surface) or hydroxyl groups (weight loss between 250 to $800^{\circ} \mathrm{C}$ ). Both, the total amount of surface, interlayer and structural water, and the structurally bound water obtained by TGA analysis for the different samples are plotted in Figure 10b. The amount of structurally bound water identified from the weight loss by TGA is higher than the quantity of water in hydroxyl groups quantified by H-NMR (Nied et al., 2016) as the TGA results include also the water present as a monolayer on the M-S-H surface (for a more detailed discussion see e.g. Roosz et al. (2016). However, this increase of hydroxyl groups at higher $\mathrm{Mg} / \mathrm{Si}$ ratio could be related to the presence of more $\mathrm{Q}^{2}$ sites as Nied et al. (2016) found that hydroxyl groups are associated to $\mathrm{Q}^{1}$ and $\mathrm{Q}^{2}$ sites and possibly also to magnesium.

The amount of $\mathrm{Q}^{3}{ }_{\mathrm{a}}$ slightly decreased with aging time while $\mathrm{Q}^{3}{ }_{\mathrm{b}}$ and $\mathrm{Q}^{3}{ }_{\mathrm{c}}$ both increased. These changes could not be fully resolved, but the increase of $\mathrm{Q}^{3}$ sites could be related to the better ordering of the silica sheet of longer aged samples, as also observed in the XRD data given in Figure $7 \mathrm{~b}$. Although the silica arrangement varies with the $\mathrm{Mg} / \mathrm{Si}$ ratio in $\mathrm{M}-\mathrm{S}-\mathrm{H}$, above $\mathrm{Mg} / \mathrm{Si}$ $=1.2$ no further increase of $\mathrm{OH} / \mathrm{Si}$ was observed and a plateau seems to be reached with $\mathrm{Q}^{2} / \mathrm{Q}^{3}=$ 1. The ${ }^{29} \mathrm{Si}$ MAS NMR spectrum at $\mathrm{Mg} / \mathrm{Si}=1.4$ is similar to the one at $\mathrm{Mg} / \mathrm{Si}=1.2$ consistent with the comparable magnesium concentrations due to the presence of brucite which buffers $\mathrm{pH}$ values and magnesium concentrations and limits the $\mathrm{Mg} / \mathrm{Si}$ ratio in $\mathrm{M}-\mathrm{S}-\mathrm{H}$ at 1.2 to 1.3.

A $\mathrm{Q}^{2} / \mathrm{Q}^{3}$ equal to 1 would be characteristic for double chain silica (amphibole) (Welch et al., 1992), such as anthophyllite $(\mathrm{Mg}, \mathrm{Fe})_{7} \mathrm{Si}_{8} \mathrm{O}_{22}(\mathrm{OH})_{2}$ or hornblende $(\mathrm{K}, \mathrm{Ca}, \mathrm{Na}, \mathrm{Fe}, \mathrm{Mg})_{2}(\mathrm{Mg}, \mathrm{Fe}, \mathrm{Al})_{5}(\mathrm{Al}, \mathrm{Si})_{8} \mathrm{O}_{22}(\mathrm{OH})_{2}$, while phyllosilicates such as talc or antigorite possess only $\mathrm{Q}^{3}$ sites. Thus the presence of a significant fraction of $\mathrm{Q}^{2}$ could be explained either by very small coherent silica regions in M-S-H (Roosz et al., 2015) or alternatively by the presence of double chain silica such as in anthophyllite or triple chain silica such as in 
jimthompsonite $\left(\mathrm{Mg}, \mathrm{Fe}^{2+}\right)_{5} \mathrm{Si}_{6} \mathrm{O}_{16}(\mathrm{OH})_{2}$ or chesterite $(\mathrm{Mg}, \mathrm{Fe})_{17} \mathrm{Si}_{20} \mathrm{O}_{54}(\mathrm{OH})_{6}$ (Nied et al., 2016; Welch et al., 1992).
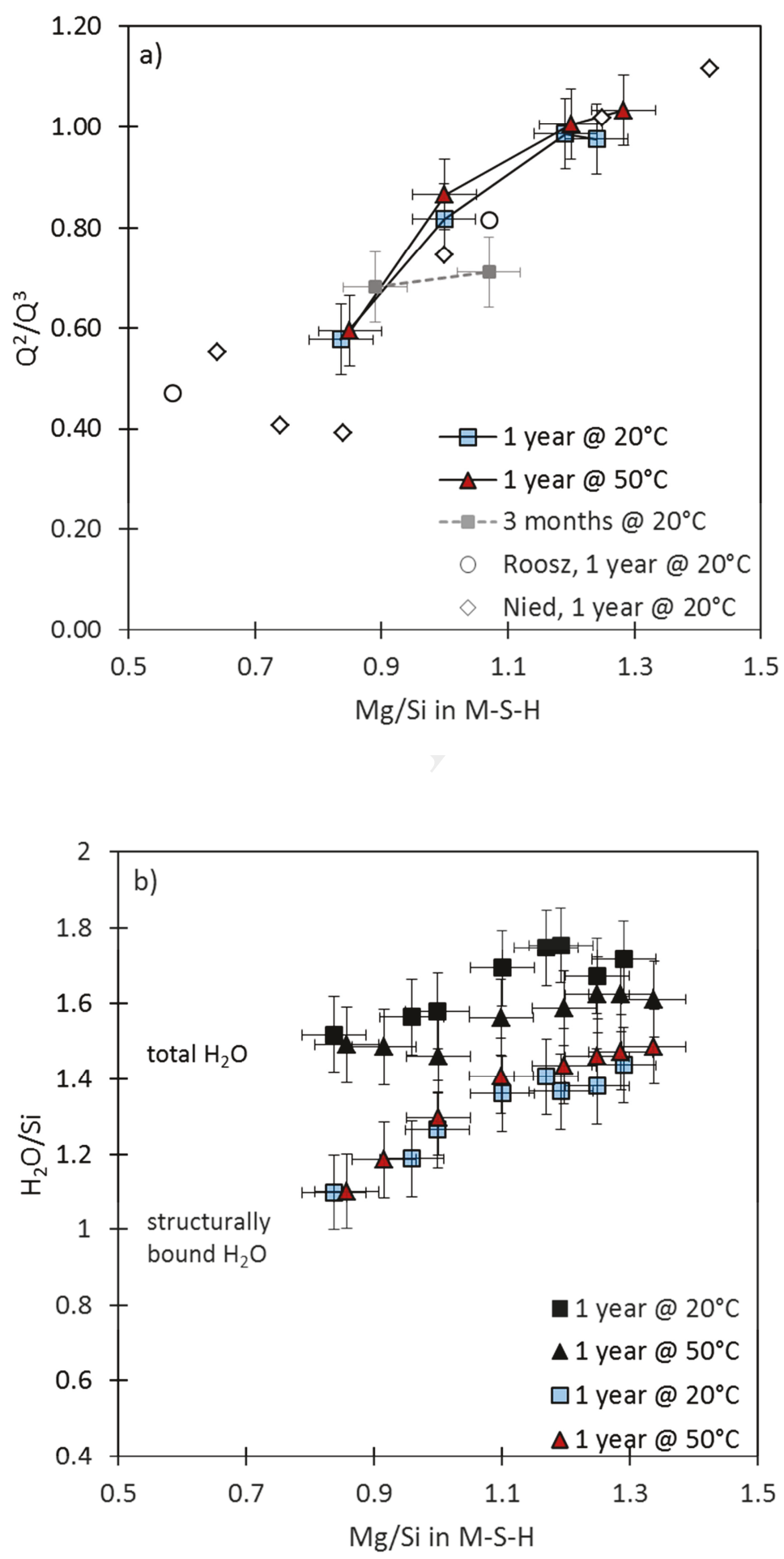
Figure 10: a) $Q^{2} / Q^{3}$ total from ${ }^{29} \mathrm{Si}$ MAS NMR as a function of the experimentally determined $M g / S i$ in $M$-S-H phases, after 3 and 12 months at $20^{\circ} \mathrm{C}$ and after 12 months at $50^{\circ} \mathrm{C}$ compared to literature data (Nied et al., 2016; Roosz et al., 2015), b) structurally bound water plus hydroxyl groups of $M$-S-H, determined from the weight loss between $270-800^{\circ} \mathrm{C}$ by TGA, and total $\mathrm{H}_{2} \mathrm{O}$, determined from the entire weight loss by TGA, per silica as a function of the $\mathrm{Mg} / \mathrm{Si}$ in $\mathrm{M}-\mathrm{S}$-H phases.

\subsection{Effect of temperature}

\subsubsection{Solution}

Temperature has a significant influence on the kinetics of M-S-H formation and its solubility.

The reaction was faster at higher temperature and the magnesium and silicon concentrations at 50 and $70^{\circ} \mathrm{C}$ were at equilibrium with $\mathrm{M}-\mathrm{S}-\mathrm{H}$ faster than at $20^{\circ} \mathrm{C}$ as visible from the silicon concentrations at 20,50 and $70^{\circ} \mathrm{C}$ shown in Figure 11 (and detailed in the Appendix). At low $\mathrm{Mg} / \mathrm{Si}$ ratios in $\mathrm{M}-\mathrm{S}-\mathrm{H}$, where unreacted silica persists, the higher silicon concentrations (from 1.2 to 1.5 , to 2.5 and to $3.8 \mathrm{mM}$ at $7{ }^{\circ} \mathrm{C}, 20^{\circ} \mathrm{C}, 50^{\circ} \mathrm{C}$ and $70^{\circ} \mathrm{C}$, respectively) simply relate to the increase of silica solubility with temperature (Gunnarsson and Arnórsson, 2000). In the presence of M-S-H without amorphous silica, lower silicon concentrations were observed at higher temperatures (Figure 11, Appendix). 

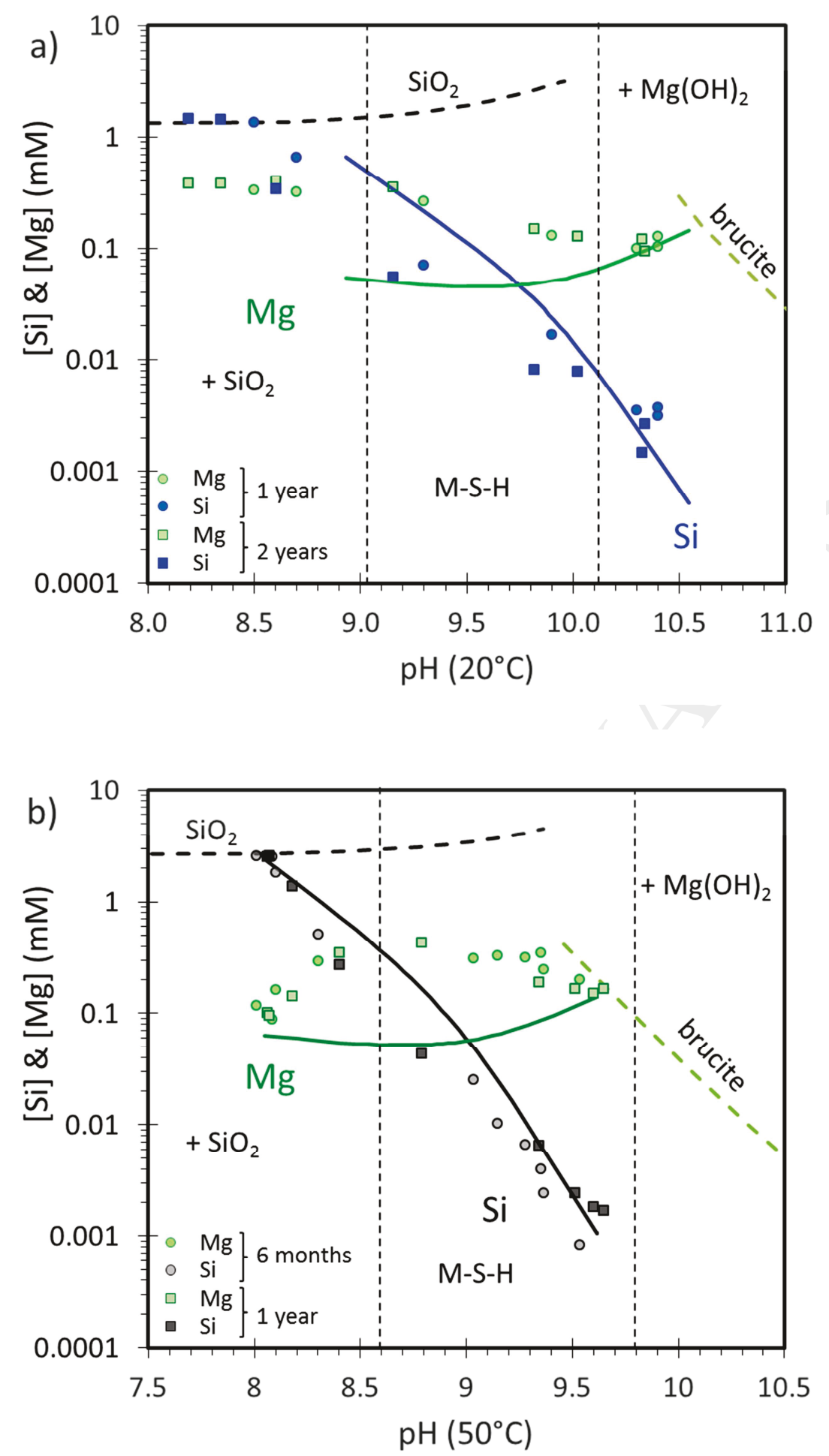


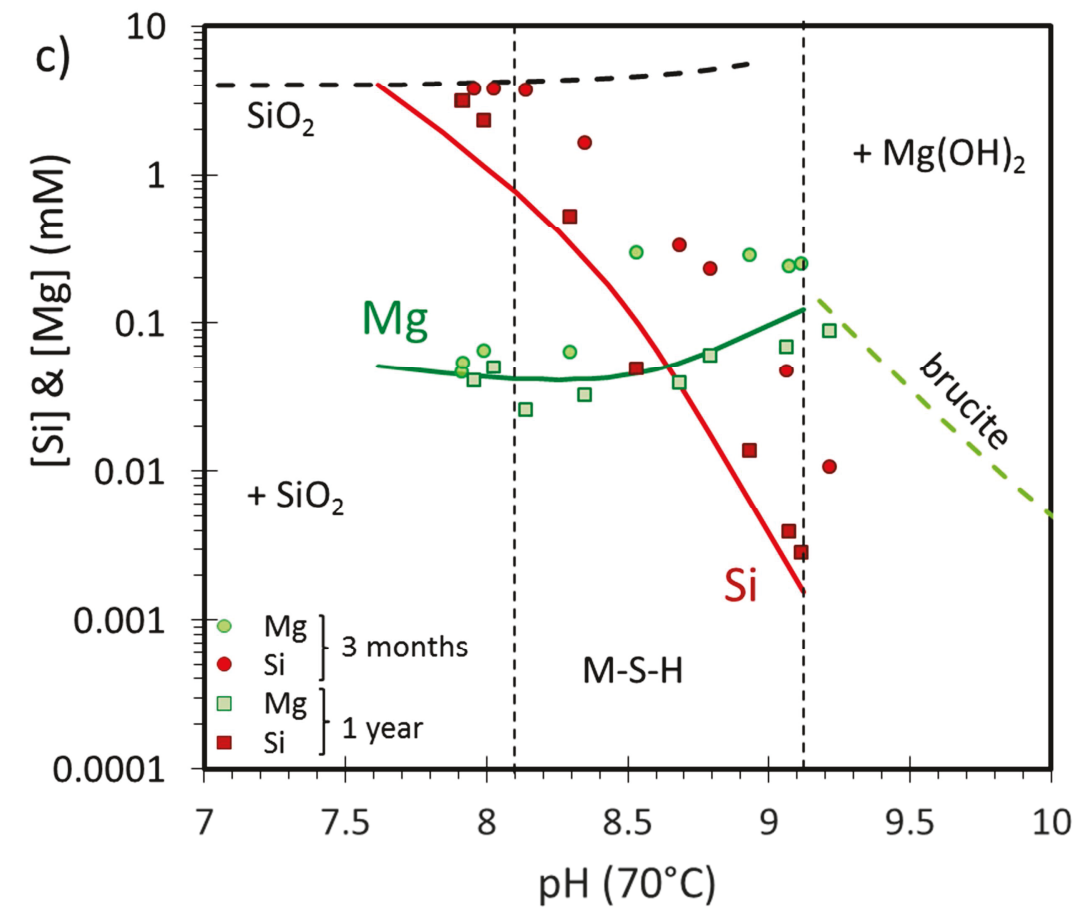

Figure 11: Magnesium (light green symbols) and silicon (dark blue, black or red symbols) concentrations as a function of $\mathrm{pH}$ a) at $20^{\circ} \mathrm{C}$ after 1 year (circles) and 2 years (squares) b) at $50^{\circ} \mathrm{C}$ after 6 months (circles) and 1 year (squares) c) at $70^{\circ} \mathrm{C}$ after 3 months (circles) and 1 year (squares). Lines indicate calculated solubility of amorphous $\mathrm{SiO}_{2}, \mathrm{M}-\mathrm{S}-\mathrm{H}$ and brucite (details in the text in section 3.3). Vertical lines separate the area where i) silica $+M-S-H$, ii) $M-S-H$ only and iii) $M-S-H+$ brucite are present.

At high $\mathrm{Mg} / \mathrm{Si}$ ratio the magnesium concentrations at all temperatures are limited by brucite solubility as shown in Figure 11. The magnesium concentrations in equilibrium with brucite are similar at $20^{\circ} \mathrm{C}$ as at $50^{\circ} \mathrm{C}$ and $70^{\circ} \mathrm{C}$ although they are shifted on the pH scale. In the absence of brucite, however, magnesium concentrations are lower at $70^{\circ} \mathrm{C}$ than at 50 and $20^{\circ} \mathrm{C}$ (Figure 11) and highest at $7^{\circ} \mathrm{C}$ (Appendix).

A strong influence of temperature was also visible in the relative changes of the magnesium concentrations as a function of $\mathrm{pH}$ and $\mathrm{Mg} / \mathrm{Si}$ ratio. At $20^{\circ} \mathrm{C}$, the magnesium concentrations decreased with increasing $\mathrm{Mg} / \mathrm{Si}$ ratio after 6 months and 1 year (Appendix), after 2 years no trend in the magnesium concentrations was observed for the low $\mathrm{Mg} / \mathrm{Si}$ samples $(\mathrm{Mg} / \mathrm{Si}=0.7$ 1.0). At $50^{\circ} \mathrm{C}$ up to 3 months such a decrease was observed, while after 6 and 12 months at $50^{\circ} \mathrm{C}$ 
(and after 3 and 12 months at $70^{\circ} \mathrm{C}$ ) a clear increase of magnesium concentrations with $\mathrm{Mg} / \mathrm{Si}$ ratio was observed. In fact, one would expect, in the absence of brucite, an increase of the magnesium concentration with increasing $\mathrm{Mg} / \mathrm{Si}$ ratio as observed at higher temperature and longer equilibration times (Figure 11b) and as reported for C-S-H gels (Haas and Nonat, 2015; L'Hôpital et al., 2015). The reason for such a strongly different behavior is not yet fully understood, but it seems that the samples were near to equilibrium after 1 year at $70{ }^{\circ} \mathrm{C}$. It can be speculated that the higher measured magnesium concentrations at $20^{\circ} \mathrm{C}$ and at $50^{\circ} \mathrm{C}$ than the calculated concentrations (see Figure 11a and b) indicate that equilibrium has not yet been completely reached even after 1 year at $50^{\circ} \mathrm{C}$ or 2 years at $20^{\circ} \mathrm{C}$.

\subsubsection{Solid phases}

Higher temperatures lead to a faster consumption of brucite and amorphous silica as visualized in Figure 8 and Figure 12. After one month, the samples cured at $50^{\circ} \mathrm{C}$ still contained brucite, but significantly less than the samples cured for 3 months at $20^{\circ} \mathrm{C}$ (Figure 8).

After 3 months at $50^{\circ} \mathrm{C}$ and $70^{\circ} \mathrm{C}$, no brucite was observed at $\mathrm{Mg} / \mathrm{Si}<1.0$ indicating a faster formation of $\mathrm{M}-\mathrm{S}-\mathrm{H}$ at higher temperature. However, at $\mathrm{Mg} / \mathrm{Si} \geq 1.2$ at $50^{\circ} \mathrm{C}$ and $70^{\circ} \mathrm{C}$ some brucite remained even after 1 year and no or very little decrease of the amount of brucite with time was observed. The $\mathrm{Mg} / \mathrm{Si}$ ratio of 1.2 to 1.3 seems to be the higher limit, due to the presence of brucite.

Figure $12 \mathrm{~b}$ and Figure 8 indicate that similar amounts of unreacted silica were observed by ${ }^{29} \mathrm{Si}$ MAS NMR at 20,50 and $70^{\circ} \mathrm{C}$ for an initial $\mathrm{Mg} / \mathrm{Si}$ ratio equal to 0.80 resulting at all temperatures in a similar minimum $\mathrm{Mg} / \mathrm{Si}$ ratio of $0.84 \pm 0.02$ (Table 4). 

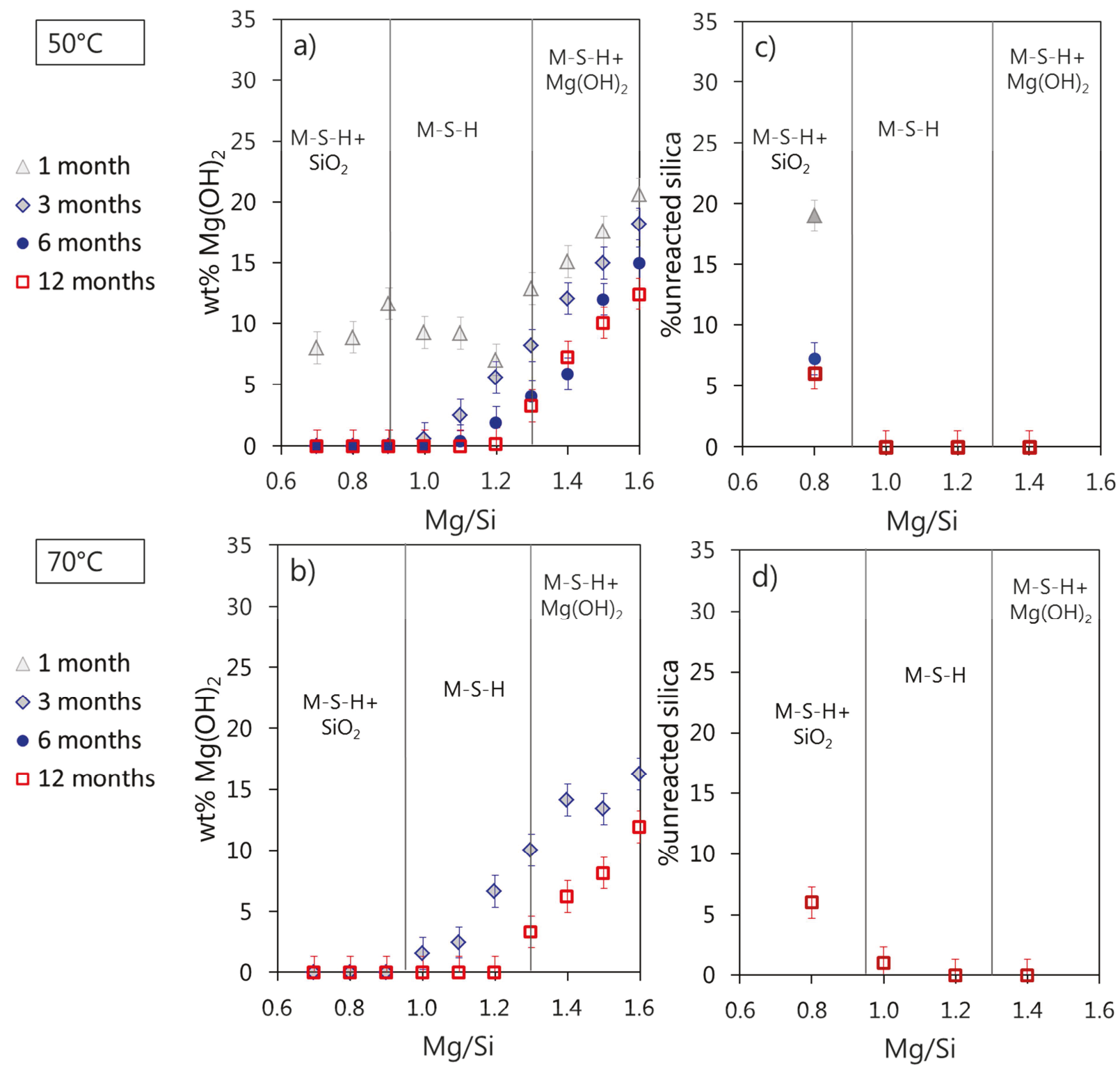

Figure 12: Amount of brucite (from TGA) (wt\% of brucite for $100 \mathrm{~g}$ dry mass) and b) unreacted silica (from ${ }^{29} \mathrm{Si}$ MAS NMR) per total of silica in samples cured a) at $50^{\circ} \mathrm{C}$ and b) $70^{\circ} \mathrm{C}$ as a function of the initial $\mathrm{Mg} / \mathrm{Si}$ and amount of unreacted silica (from the ${ }^{29} \mathrm{Si} M A S N M R$ ) in samples cured c) at $50^{\circ} \mathrm{C}$ and d) $70^{\circ} \mathrm{C}$ as a function of the initial Mg/Si. Vertical lines separate the area where i) silica $+M-S-H$, ii) $M-S-H$ only and iii) $M-S-H+$ brucite are present after long reaction times. 


\subsection{Solubility}

\subsubsection{Ion activity products of $\mathrm{M}-\mathrm{S}-\mathrm{H}$ as a function of time}

Initially, a transitional M-S-H was formed with an experimentally determined $\mathrm{Mg} / \mathrm{Si}$ ratio in the range of $0.9-1.1$ independently of the total $\mathrm{Mg} / \mathrm{Si}$ ratio. Ion activity products $\left(\left\{\mathrm{Mg}^{2+}\right\}\left\{\mathrm{SiO}_{2}{ }^{0}\right.\right.$ \}$\left\{\mathrm{OH}^{-}\right\}^{2}\left\{\mathrm{H}_{2} \mathrm{O}\right\}^{0.6}$ ) corresponding to $\mathrm{MgSiO}_{4.6} \mathrm{H}_{3.2}$ were calculated with GEMS (Kulik et al., 2013) for samples with $\mathrm{Mg} / \mathrm{Si}=0.9,1.0,1.1$ (bold values in the Appendix) for all investigated equilibration times. A decrease of ion activity products with time was clearly observed indicating the formation of a more stable M-S-H. Between 6 months and 1 year at $50^{\circ} \mathrm{C}$ no further decrease in the calculated solubility products with time was found. The values obtained at 50 and $70^{\circ} \mathrm{C}$ after 1 year are slightly higher than the ion activity product obtained at $20^{\circ} \mathrm{C}$ after 2 years.

\subsubsection{Solubility products of M-S-H}

At later ages $\left(2\right.$ years at $20^{\circ} \mathrm{C}, 1$ year at 50 and $70^{\circ} \mathrm{C}$ ) where better defined and distinct M-S-H compositions were present, two separate solubility products for high and low $\mathrm{Mg} / \mathrm{Si}$ in $\mathrm{M}-\mathrm{S}-\mathrm{H}$ were calculated. Nied et al. (2016) developed a solid solution model for M-S-H using two end members $\mathrm{M}_{3} \mathrm{~S}_{4} \mathrm{H}_{5}$ and $\mathrm{M}_{3} \mathrm{~S}_{2} \mathrm{H}_{5}$ representing $\mathrm{Mg} / \mathrm{Si}$ ratios of 0.75 and 1.5. The present more detailed investigations show a minimum $\mathrm{Mg} / \mathrm{Si}$ ratio of $\sim 0.8$ and a maximum $\mathrm{Mg} / \mathrm{Si}$ ratio of 1.3, thus $\mathrm{Mg} / \mathrm{Si}$ ratios of 0.78 and of 1.30 were selected as end-members. The solubility products of these end-members are summarized in Table 5.

For low $\mathrm{Mg} / \mathrm{Si}$ ratio (0.7-1.0) the solubility products of M-S-H phases $\left(\mathrm{Mg}_{0.78} \mathrm{Si}_{1} \mathrm{O}_{4.26} \mathrm{H}_{2.96} \Leftrightarrow\right.$ $\left.0.78 \mathrm{Mg}^{2+}+\mathrm{SiO}_{2}{ }^{0}+1.56 \mathrm{OH}^{-}+0.7 \mathrm{H}_{2} \mathrm{O}\right)$ were calculated based only on samples where both M-S$\mathrm{H}$ and silica were present. The averages of these solubility products are listed in Table 5 , and the resulting solubility products show a clear decrease with time and slight increase with temperature as shown in Figure 13. Similarly, for samples where M-S-H and brucite were both present (see 
the Appendix), the solubility products for $\mathrm{M}-\mathrm{S}-\mathrm{H}$ phases with $\mathrm{Mg} / \mathrm{Si}=1.30$ were calculated accordingly: $\mathrm{Mg}_{1.3} \mathrm{Si}_{1} \mathrm{O}_{5.1} \mathrm{H}_{3.6} \Leftrightarrow 1.3 \mathrm{Mg}^{2+}+\mathrm{SiO}_{2}{ }^{0}+2.6 \mathrm{OH}^{-}+0.5 \mathrm{H}_{2} \mathrm{O}$ and their average values are given in Table 5. As at lower $\mathrm{Mg} / \mathrm{Si}$, the solubility products decrease with time and increase slightly with temperature. The calculated ion activities for the dissolution of crystalline talc and antigorite (Table 5) are lower than the calculated solubility products of M-S-H samples.

Finally, the heat capacity of the two end-members presented in Table 6 was estimated from the heat capacities of talc, antigorite and chrysotile as given in (Holland and Powell, 1998) and water content, assuming $\Delta_{r} C_{p} \approx 0$. The entropy given in Table 6 was adapted to fit the increase of the solubility with the temperature as shown in Figure 13.

Table 5: Calculated solubility products of $\mathrm{M}_{0.78} \mathrm{SH}_{1.48}\left(\left\{\mathrm{Mg}^{2+}\right\}^{0.78}\left\{\mathrm{SiO}_{2}^{0}\right\}\{\mathrm{OH}\}^{1.56}\left\{\mathrm{H}_{2} \mathrm{O}\right\}^{0.7}\right\}$ and of $\mathrm{Mg}_{1.30} \mathrm{SiH}_{1.80}$ $\left.\left(\left\{\mathrm{Mg}^{2+}\right\}^{1.3}\left\{\mathrm{SiO}_{2}{ }^{0}\right\} \mathrm{OH}^{-}\right\}^{2.6}\left\{\mathrm{H}_{2} \mathrm{O}\right\}^{0.5}\right)$, data averaged from bold values in Appendix.

\begin{tabular}{|c|c|c|c|c|c|}
\hline \multirow{2}{*}{$\mathrm{M}_{0.78} \mathrm{SH}_{1.48}$} & \multicolumn{3}{|c|}{$\log K_{S 0} \pm 0.5$} & \multirow[b]{2}{*}{1 year } & \multirow[b]{2}{*}{2 years } \\
\hline & 1 month & 3 months & 6 months & & \\
\hline $7^{\circ} \mathrm{C}$ & & & & $-14.8^{*}$ & \multirow{4}{*}{-14.8} \\
\hline $20^{\circ} \mathrm{C}$ & \multirow{3}{*}{-13.4} & -13.0 & -14.1 & -14.5 & \\
\hline $50^{\circ} \mathrm{C}$ & & -13.5 & -13.9 & -13.9 & \\
\hline $70^{\circ} \mathrm{C}$ & & -13.4 & & -13.6 & \\
\hline \multirow{2}{*}{$\mathrm{M}_{1.30} \mathrm{SH}_{1.60}$} & \multicolumn{3}{|c|}{$\log K_{s 0} \pm 0.5$} & & \\
\hline & 1 month & 3 months & 6 months & 1 year & 2 years \\
\hline $7^{\circ} \mathrm{C}$ & & & & $-22.6^{*}$ & \\
\hline $20^{\circ} \mathrm{C}$ & & -18.2 & -18.3 & -21.2 & -21.6 \\
\hline $50^{\circ} \mathrm{C}$ & -19.6 & -19.1 & -20.4 & -20.6 & \\
\hline $70^{\circ} \mathrm{C}$ & & -19.8 & & -20.2 & \\
\hline
\end{tabular}

* Approximate value after 18 months from undersaturation, equilibrium might not yet have been reached

Table 6: Tentative thermodynamic properties of the end-members $M_{0.78} S H_{1.48}$ and $M_{1.30} S H_{1.60}$ at the standard conditions $\left(25^{\circ} \mathrm{C}\right.$ and $\left.1 \mathrm{~atm}\right) . \mathrm{Log} \mathrm{K}_{\mathrm{s}}$ designates the solubility product with respect to $\mathrm{Mg}^{2+}, \mathrm{SiO}_{2}, \mathrm{OH}^{-}$and $\mathrm{H}_{2} \mathrm{O}, \Delta_{f} \mathrm{G}^{0}$ Gibbs free energy of formation, $\Delta_{f} H^{0}$ enthalpy of formation; $S^{0}$ entropy; $C^{0}{ }_{p}$ heat capacity $\left(C^{0} p=a+b T+c T^{-2}+d T^{-1 / 2}\right)$. 


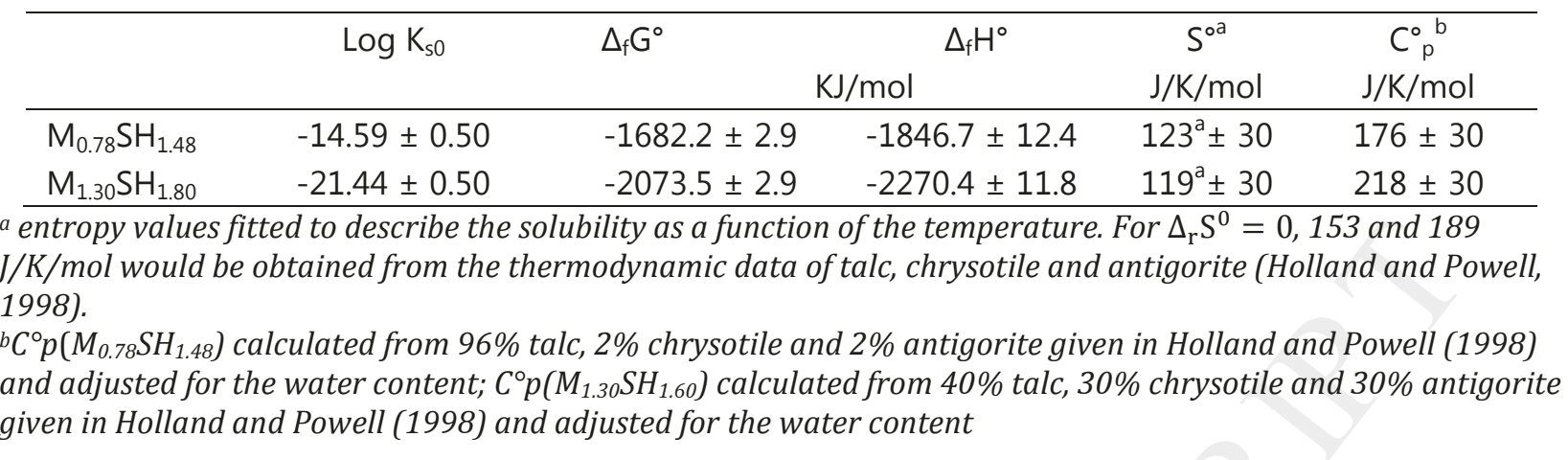

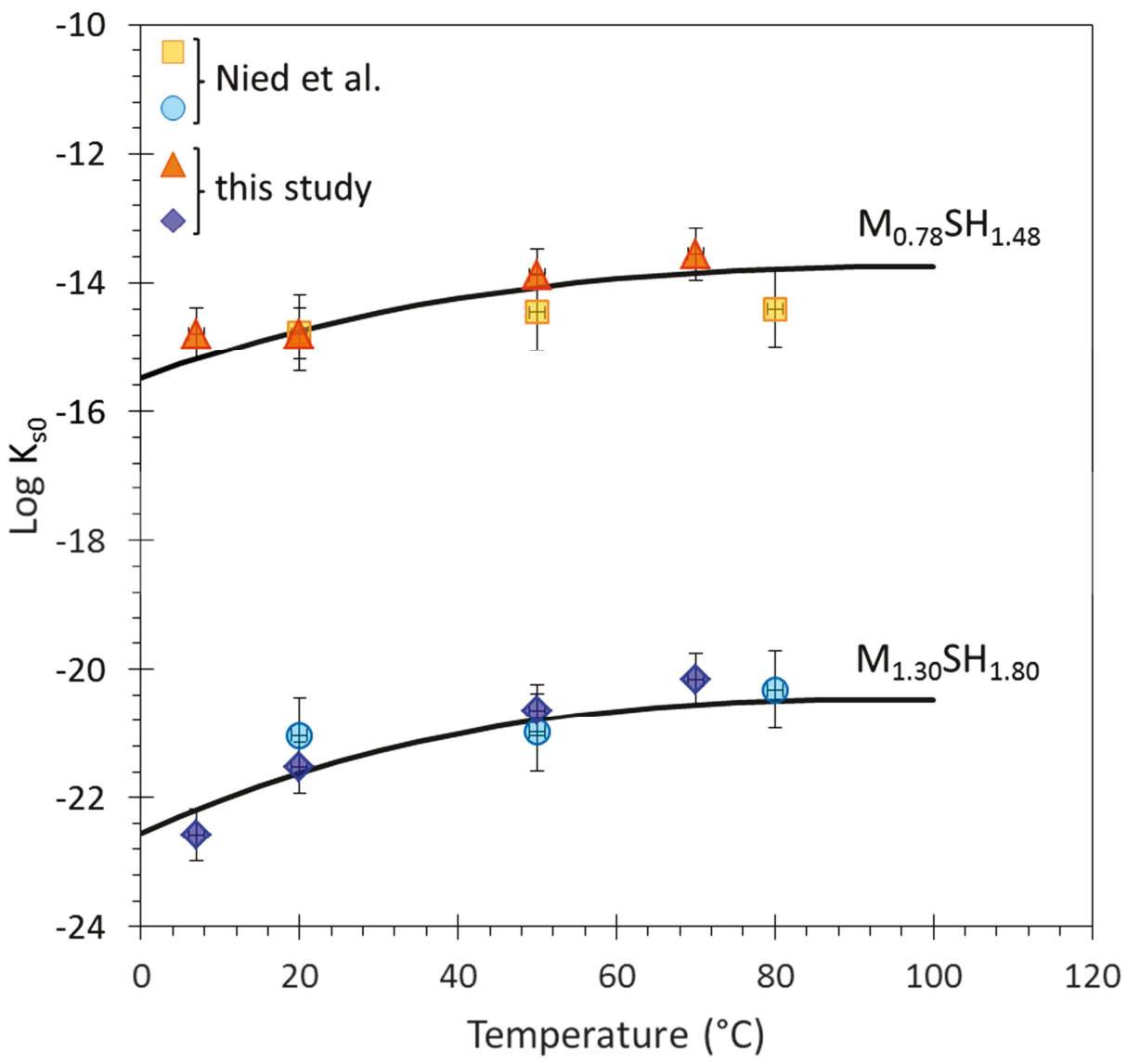

Figure 13: Changes of the solubility product as a function of temperature. Triangle and diamonds indicate the average of the experimental data given in Table 5, squares and circles the data from Nied et al. (2016) after 1 year and from Nied et al. (2011) after 3 months. The lines indicate the solubility calculated from the thermodynamic data in Table 6. 


\section{Conclusions}

The formation of M-S-H from $\mathrm{MgO}$ and $\mathrm{SiO}_{2}$ is a slow process which continues at least up to 2 years at $20^{\circ} \mathrm{C}$ and possibly longer. During the first day, the fast dissolution of $\mathrm{MgO}$ and the precipitation of brucite and of a small amount of M-S-H was observed. Silica fume dissolved more slowly. However, after one week and longer the solutions were equilibrated with respect to amorphous silica. Although brucite presence persisted at all $\mathrm{Mg} / \mathrm{Si}$ ratio up to 3 months, the solutions were undersaturated with respect to brucite after 2 days indicating that the dissolution of brucite is the rate limiting step for the formation of M-S-H. It can be speculated that the presence of silicon in solution is responsible for the observed slow brucite dissolution.

In presence of both, silica and brucite, initially a transitional $\mathrm{M}-\mathrm{S}-\mathrm{H}$ phases with a $\mathrm{Mg} / \mathrm{Si}$ ratio of 0.9-1.1 is formed, independently of the total $\mathrm{Mg} / \mathrm{Si}$ ratio in the sample. The formation of such an initial $\mathrm{M}-\mathrm{S}-\mathrm{H}$ with $\mathrm{Mg} / \mathrm{Si} \approx 1$ in presence of amorphous silica and brucite is consistent with literature data on the properties of M-S-H after short equilibration times where generally only the formation of M-S-H with a Mg/Si ratio of approximately 1 is reported (Brew and Glasser, 2005a; Brew and Glasser, 2005b; d'Espinose de Lacaillerie et al., 1995; Li et al., 2014; Szczerba et al., 2013; Zhang et al., 2011). Only in a few studies where longer equilibration times had been monitored, a wider range of $\mathrm{Mg} / \mathrm{Si}$ ratio was observed (Kalousek and Mui, 1954; Nied et al., 2016; Roosz et al., 2015), consistent with the present study where a broader range of $\mathrm{Mg} / \mathrm{Si}$ ratio from 0.8 to 1.3 in the solid was observed after longer storage and slightly different structures started to evolve depending on the initial $\mathrm{Mg} / \mathrm{Si}$ ratio.

The M-S-H phases formed undergo a slow ripening process resulting in less soluble M-S-H after longer equilibration times. At 50 and $70^{\circ} \mathrm{C}$ the $\mathrm{M}-\mathrm{S}-\mathrm{H}$ formation occurred faster, but a similar gel-like structure of $\mathrm{M}-\mathrm{S}-\mathrm{H}$ and a comparable range of $\mathrm{Mg} / \mathrm{Si}$ ratio were observed at $20^{\circ} \mathrm{C}$. The 
calculated solubilities of M-S-H are similar range to those reported in a previous study (Nied et al., 2016) and comparable to the solubility of crystalline magnesium silicate hydrates such as talc or antigorite investigated in this study or to talc and antigorite/chrysotile as reported in the literature (Helgeson, 1978; Holland and Powell, 1998; Melekhova et al., 2006; Tardy and Duplay, 1992) and as shown in Figure 14.

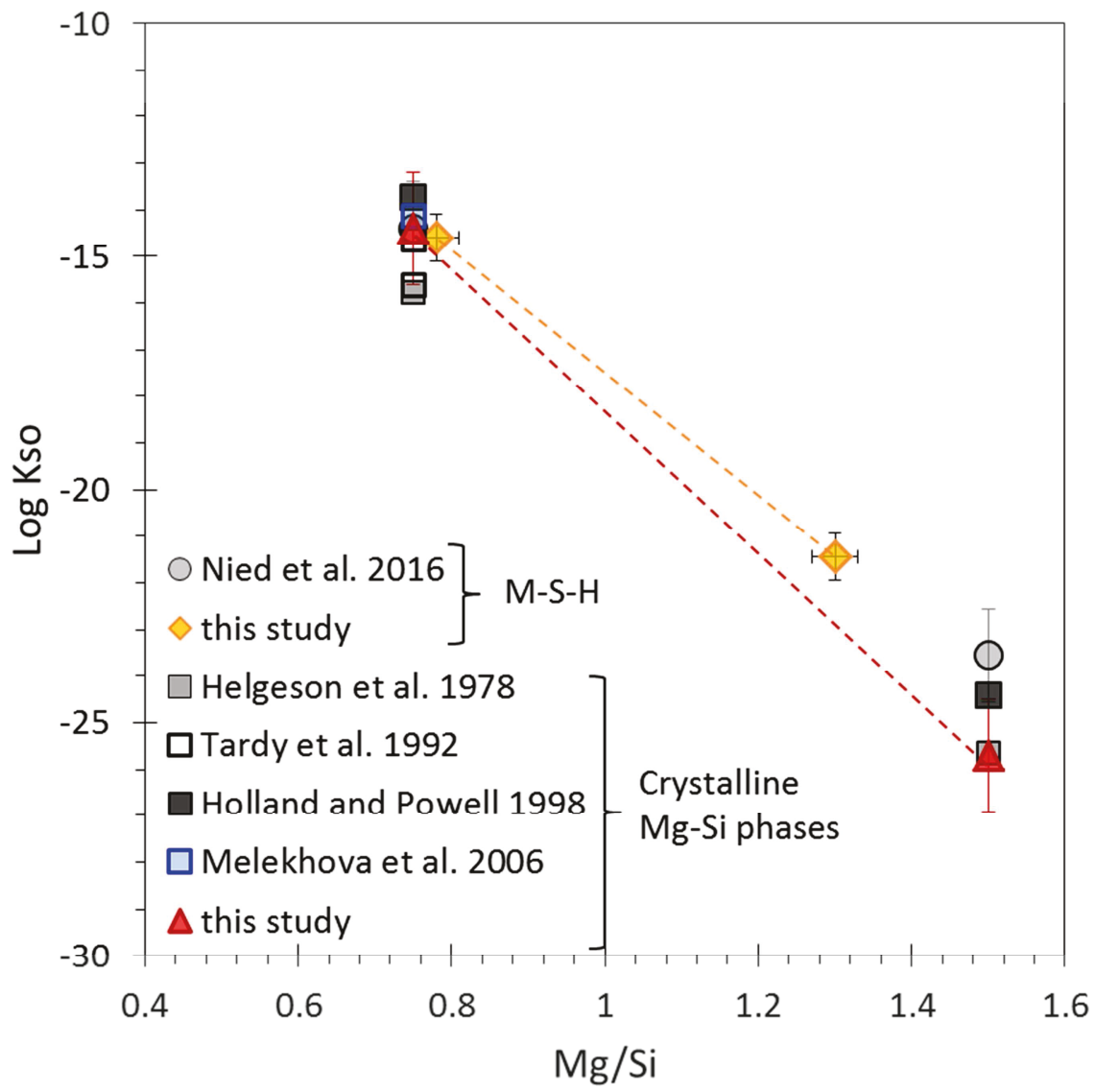

Figure 14: Evolution of the solubility product at $25^{\circ} \mathrm{C}$ as a function of the initial Mg/Si (with Si = 1), triangles and diamonds correspond to the experimental data presented in the Appendix and the Table 6, while others are adapted from literature (Helgeson, 1978; Holland and Powell, 1998; Melekhova et al., 2006; Nied et al., 2016; Tardy and Duplay, 1992) for comparison. 


\section{Acknowledgements}

The authors would like to thank Céline Cau-Dit-Coumes, Andreas Jenni, Dimitrii Kulik, Émilie L'Hôpital, and Dominik Nied for helpful discussions and providing reference samples and to Luigi Brunetti, Boris Ingold and Beatrice Fischer for support in the preparation of the samples and analysis. The NMR hardware was partially granted by the Swiss National Science Foundation (SNFS, grant no. 150638).

\section{Appendix}

Appendix: Summary of the experimentally determined Mg/Si molar ratios, presence of brucite and/or silica fume, $p H$ values, measured dissolved concentrations in the solutions in equilibrium with the synthesized M-S-H samples and calculated ion activity products of $\mathrm{M}-\mathrm{S}-\mathrm{H}$ with $\mathrm{Mg} / \mathrm{Si}=0.78,1.00$ and 1.30 .

\begin{tabular}{|c|c|c|c|c|c|c|c|c|c|c|c|}
\hline temp. & $\begin{array}{c}\text { equilibration } \\
\text { time }\end{array}$ & $\begin{array}{l}\text { initial } \\
\mathrm{Mg} / \mathrm{Si}\end{array}$ & $\mathrm{Mg} / \mathrm{Si}$ & brucite $^{a}$ & $\begin{array}{c}\text { unreacted } \\
\text { silica }^{\mathrm{b}}\end{array}$ & $\begin{array}{c}\mathrm{pH} \\
\left(20^{\circ} \mathrm{C}\right)\end{array}$ & $\begin{array}{l}{[\mathrm{Mg}]} \\
\mathrm{mM}\end{array}$ & $\begin{array}{l}{[\mathrm{Si}]} \\
\mathrm{mM} \\
\end{array}$ & $\mathrm{M}_{0.78} \mathrm{SH}_{1.48}$ & $\begin{array}{l}\log \mathrm{K}_{\mathrm{s} 0} \\
\mathrm{MSH}_{1.60}\end{array}$ & $\mathrm{M}_{1.30} \mathrm{SH}_{1.80}$ \\
\hline \multicolumn{12}{|c|}{ Undersaturation } \\
\hline \multirow[t]{2}{*}{$7^{\circ} \mathrm{C}$} & 1.5 Years & 0.8 & n.d. & & $x$ & 8.6 & 1.14 & 1.19 & -14.8 & -13.9 & -22.7 \\
\hline & & 1.2 & n.d. & $x$ & & 9.7 & 1.35 & 0.003 & -15.8 & -14.4 & -22.6 \\
\hline \multicolumn{12}{|c|}{ Oversaturation } \\
\hline \multirow[t]{18}{*}{$20^{\circ} \mathrm{C}$} & 3 months & 0.8 & 0.81 & $x$ & $x$ & 9.6 & 0.28 & 1.54 & -13.6 & -16.6 & -20.7 \\
\hline & & 0.9 & n.d. & $x$ & $x$ & 9.3 & 0.26 & 1.53 & -13.1 & -15.9 & -19.8 \\
\hline & & 1.0 & n.d. & $x$ & $x$ & 9.5 & 0.20 & 1.51 & -12.7 & -15.4 & -19.0 \\
\hline & & 1.1 & n.d. & $x$ & $x$ & 9.5 & 0.18 & 1.52 & -12.5 & -15.0 & -18.4 \\
\hline & & 1.2 & n.d. & $x$ & $x$ & 9.4 & 0.13 & 1.52 & -12.5 & -15.1 & -18.5 \\
\hline & & 1.3 & n.d. & $x$ & $x$ & 9.5 & 0.26 & 1.29 & -12.3 & -14.7 & -18.0 \\
\hline & & 1.4 & 1.09 & $x$ & $x$ & 9.3 & 0.21 & 1.14 & -12.5 & -14.9 & -18.1 \\
\hline & 6 months & 0.8 & n.d. & & $x$ & 9.1 & 0.32 & 1.24 & -14.5 & -17.6 & -22.1 \\
\hline & & 0.9 & n.d. & & $x$ & 9.5 & 0.34 & 0.20 & -13.7 & -16.4 & -20.4 \\
\hline & & 1.0 & $1.00^{c}$ & $\mathrm{x}$ & & 10.0 & 0.26 & 0.06 & -13.6 & -16.0 & -19.5 \\
\hline & & 1.1 & $1.03^{c}$ & $x$ & & 10.5 & 0.29 & 0.05 & -13.0 & -15.0 & -18.1 \\
\hline & & 1.2 & $1.14^{\mathrm{c}}$ & $x$ & & 10.6 & 0.21 & 0.011 & -13.5 & -15.5 & -18.7 \\
\hline & & 1.3 & $1.17^{\mathrm{c}}$ & $x$ & & 10.7 & 0.17 & 0.013 & -13.4 & -15.5 & -18.6 \\
\hline & & 1.4 & $1.20^{c}$ & $x$ & & 10.7 & 0.03 & 0.42 & -12.3 & -14.4 & -17.6 \\
\hline & 1 Year & 0.8 & 0.84 & & $x$ & 8.5 & 0.33 & 1.36 & -14.5 & -17.8 & -22.3 \\
\hline & & 0.9 & n.d. & & $x$ & 8.7 & 0.32 & 0.66 & -14.6 & -17.8 & -22.2 \\
\hline & & 1.0 & 1.00 & & & 9.3 & 0.26 & 0.07 & -14.6 & -17.6 & -21.5 \\
\hline & & 1.1 & $1.10^{c}$ & & & 9.9 & 0.13 & 0.02 & -14.8 & -17.5 & -21.2 \\
\hline
\end{tabular}




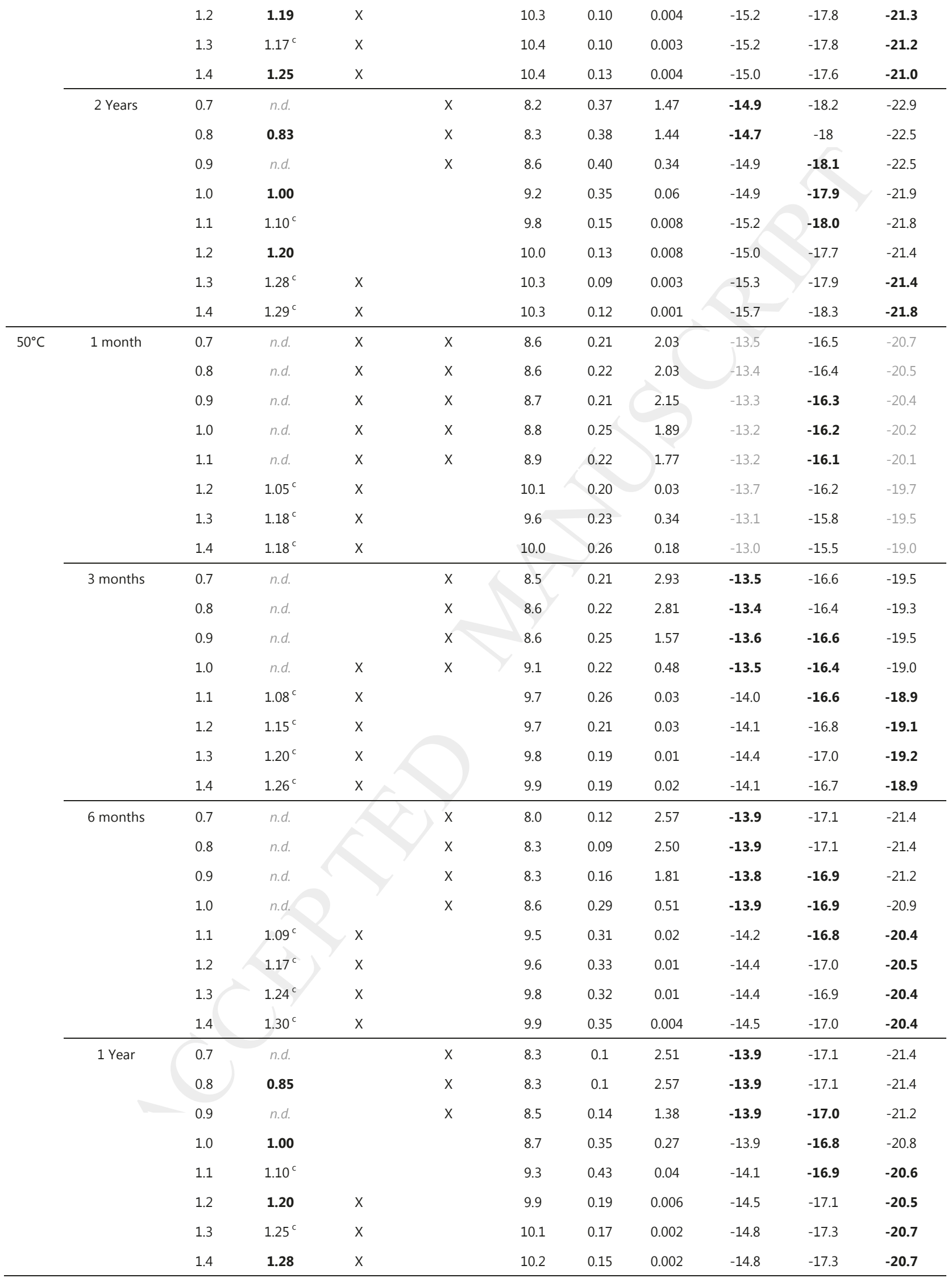




\begin{tabular}{|c|c|c|c|c|c|c|c|c|c|c|c|}
\hline \multirow[t]{16}{*}{$70^{\circ} \mathrm{C}$} & \multirow{8}{*}{3 months } & 0.7 & n.d. & & $x$ & 8.5 & 0.05 & 3.76 & -13.3 & -16.4 & -20.5 \\
\hline & & 0.8 & n.d. & & $x$ & 8.7 & 0.03 & 3.70 & -13.4 & -16.4 & -20.6 \\
\hline & & 0.9 & n.d. & & $x$ & 8.4 & 0.04 & 3.77 & -13.6 & -16.8 & -21.1 \\
\hline & & 1.0 & n.d. & $x$ & $x$ & 9.0 & 0.03 & 1.62 & -13.3 & -16.3 & -20.3 \\
\hline & & 1.1 & $1.14^{c}$ & $x$ & & 9.5 & 0.04 & 0.33 & -12.9 & -15.7 & -19.6 \\
\hline & & 1.2 & $1.17^{c}$ & $x$ & & 9.6 & 0.06 & 0.227 & -13.3 & -16.1 & -19.7 \\
\hline & & 1.3 & $1.20^{c}$ & $x$ & & 10.0 & 0.07 & 0.047 & -13.7 & -16.2 & -19.8 \\
\hline & & 1.4 & $1.24^{c}$ & $x$ & & 10.3 & 0.09 & 0.011 & -14.0 & -16.5 & -19.9 \\
\hline & \multirow[t]{8}{*}{1 Year } & 0.7 & n.d. & & $x$ & 8.3 & 0.05 & 3.11 & -13.6 & -16.7 & -21.0 \\
\hline & & 0.8 & 0.86 & & $x$ & 8.3 & 0.05 & 3.12 & -13.5 & -16.6 & -20.8 \\
\hline & & 0.9 & n.d. & & $x$ & 8.4 & 0.07 & 2.28 & -13.5 & -16.5 & -20.7 \\
\hline & & 1.0 & 1.00 & & $x$ & 8.9 & 0.06 & 0.51 & -13.7 & -16.6 & -20.6 \\
\hline & & 1.1 & $1.10^{\mathrm{c}}$ & & & 9.2 & 0.29 & 0.05 & -13.8 & -16.5 & -20.1 \\
\hline & & 1.2 & 1.20 & & & 9.8 & 0.28 & 0.014 & -13.9 & -16.4 & -19.8 \\
\hline & & 1.3 & $1.25^{c}$ & & & 10.0 & 0.24 & 0.004 & -14.3 & -16.8 & -20.1 \\
\hline & & 1.4 & 1.30 & $x$ & & 10.1 & 0.25 & 0.003 & -14.4 & -16.8 & -20.2 \\
\hline \multicolumn{12}{|c|}{ Undersaturation } \\
\hline \multirow[t]{2}{*}{$20^{\circ} \mathrm{C}$} & \multirow[t]{2}{*}{1 Year } & 0.75 & talc & & & 8.6 & 0.16 & 0.35 & $-15^{d}$ & - & - \\
\hline & & 1.5 & antigorite & & & 8.2 & 0.18 & 0.13 & - & - & $-23^{d}$ \\
\hline \multicolumn{12}{|c|}{$\begin{array}{l}\text { aX= observed by TGA and } \\
\text { Figure } 8 \text { and Figure 12) } \\
c=\text { unreacted silica negligi }\end{array}$} \\
\hline \multicolumn{12}{|c|}{$\begin{array}{l}\text { Calculated ion activity products in bold correspond to the values used for the averaged values in Table } 5 \text {, } \\
\text { values in grey correspond to samples dominated by transitional M-S-H and are given for comparison only } \\
\text { n.d.= not determined } \\
{ }^{d S y n t h e t i c ~ t a l c ~(A l f a ~ A e s a r) ~} \log K_{s 0}\left(M_{3} S_{4} H_{2}\right)=-58.0 ; \text { natural antigorite (from Binntal) } \log K_{s 0}\left(M_{3} S_{2} H_{2}\right)=-51.8\end{array}$} \\
\hline
\end{tabular}

\section{References}

Anderson, G.M., Crerar, D.A., 1993. Thermodynamics in Geochemistry: the Equilibrium Model. Oxford University Press, Oxford.

Brantley, S.L., Kubicki, J.D., White, A.F., 2008. Kinetics of Water-Rock Interaction. Springer.

Brew, D., Glasser, F., 2005a. The magnesia-silica gel phase in slag cements: alkali (K, Cs) sorption potential of synthetic gels. Cement and Concrete Research 35, 77-83.

Brew, D.R.M., Glasser, F.P., 2005b. Synthesis and characterisation of magnesium silicate hydrate gels. Cement and Concrete Research 35, 85-98.

Chabrol, K., Gressier, M., Pebere, N., Menu, M.-J., Martin, F., Bonino, J.-P., Marichal, C., Brendle, J., 2010. Functionalization of synthetic talc-like phyllosilicates by alkoxyorganosilane grafting. Journal of Materials Chemistry 20, 9695-9706.

Cong, X., Kirkpatrick, R.J., 1996. ${ }^{29}$ Si MAS NMR study of the structure of calcium silicate hydrate. Advanced Cement Based Materials 3, 144-156. 
d'Espinose de Lacaillerie, J.-B., Kermarec, M., Clause, O., 1995. ${ }^{29}$ Si NMR observation of an amorphous magnesium silicate formed during impregnation of silica with $\mathrm{Mg}(\mathrm{II})$ in aqueous solution. The Journal of Physical Chemistry 99(47), 17273-17281.

Dauzères, A., Achiedo, G., Nied, D., Bernard, E., Alahrache, S., Lothenbach, B., 2016. Magnesium perturbation in low-pH concretes placed in clayey environment-solid characterizations and modeling. Cement and Concrete Research 79, 137-150.

Dauzères, A., Le Bescop, P., Cau-Dit-Coumes, C., Brunet, F., Bourbon, X., Timonen, J., Voutilainen, M., Chomat, L., Sardini, P., 2014. On the physico-chemical evolution of low-pH and CEM I cement pastes interacting with Callovo-Oxfordian pore water under its in situ $\mathrm{CO}_{2}$ partial pressure. Cement and Concrete Research 58, 76-88.

Deschner, F., Winnefeld, F., Lothenbach, B., Seufert, S., Schwesig, P., Dittrich, S., GoetzNeunhoeffer, F., Neubauer, J., 2012. Hydration of Portland cement with high replacement by siliceous fly ash. Cement and Concrete Research 42, 1389-1400.

Dumas, A., Martin, F., Le Roux, C., Micoud, P., Petit, S., Ferrage, E., Brendlé, J., Grauby, O., Greenhill-Hooper, M., 2013. Phyllosilicates synthesis: a way of accessing edges contributions in NMR and FTIR spectroscopies. Example of synthetic talc. Physics and Chemistry of Minerals 40, 361-373.

Garcia Calvo, J.L., Hidalgo, A., Alonso, C., Fernández Luco, L., 2010. Development of low-pH cementitious materials for HLRW repositories: Resistance against ground waters aggression. Cement and Concrete Research 40, 1290-1297.

Gionis, V., Kacandes, G.H., Kastritis, I.D., Chryssikos, G.D., 2006. On the structure of palygorskite by mid-and near-infrared spectroscopy. American Mineralogist 91, 1125-1133.

Golubeva, O.Y., Korytkova, E., Gusarov, V., 2005. Hydrothermal synthesis of magnesium silicate montmorillonite for polymer-clay nanocomposites. Russian journal of applied chemistry 78, 26-32.

Gunnarsson, I., Arnórsson, S., 2000. Amorphous silica solubility and the thermodynamic properties of $\mathrm{H}_{4} \mathrm{SiO}_{4}$ in the range of 0 to $350^{\circ} \mathrm{C}$ at $\mathrm{P}_{\text {sat }}$. Geochimica et Cosmochimica Acta 64, 2295-2307.

Haas, J., Nonat, A., 2015. From C-S-H to C-A-S-H: Experimental study and thermodynamic modelling. Cement and Concrete Research 68, 124-138.

Helgeson, H.C., 1978. Summary and critique of the thermodynamic properties of rock-forming minerals. American Journal of Science 278, 1-229.

Holland, T., Powell, R., 1998. An internally consistent thermodynamic data set for phases of petrological interest. Journal of metamorphic Geology 16, 309-343.

Jenni, A., Mäder, U., Lerouge, C., Gaboreau, S., Schwyn, B., 2014. In situ interaction between different concretes and Opalinus clay. Physics and Chemistry of the Earth, Parts A/B/C 70, 7183.

Jin, F., Al-Tabbaa, A., 2013. Thermogravimetric study on the hydration of reactive magnesia and silica mixture at room temperature. Thermochimica Acta 566, 162-168.

Kalousek, G.L., Mui, D., 1954. Studies on formation and recrystallization of intermediate reaction products in the system magnesia-silica-water. Journal of the American Ceramic Society 37, 38-42.

Kulik, D., 2002. Minimising uncertainty induced by temperature extrapolations of thermodynamic data: a pragmatic view on the integration of thermodynamic databases into geochemical computer codes, The use of thermodynamic databases in performance assessment. OECD, Barcelona, pp. 125-137. 
Kulik, D.A., Wagner, T., Dmytrieva, S.V., Kosakowski, G., Hingerl, F.F., Chudnenko, K.V., Berner, U.R., 2013. GEM-Selektor geochemical modeling package: revised algorithm and GEMS3K numerical kernel for coupled simulation codes. Computational Geosciences 17, 1-24.

L'Hôpital, E., Lothenbach, B., Le Saout, G., Kulik, D., Scrivener, K., 2015. Incorporation of aluminium in calcium-silicate-hydrates. Cement and Concrete Research 75, 91-103.

Li, Z., Zhang, T., Hu, J., Tang, Y., Niu, Y., Wei, J., Yu, Q., 2014. Characterization of reaction products and reaction process of $\mathrm{MgO}-\mathrm{SiO}_{2}-\mathrm{H}_{2} \mathrm{O}$ system at room temperature. Construction and Building Materials 61, 252.

Lothenbach, B., Durdzinski, P., DeWeerdt, K., 2016. Thermogravimetric analysis, in: Scrivener, K., Snellings, R., Lothenbach, B. (Eds.), A Practical Guide to Microstructural Analysis of Cementitious Materials. CRC Press, Oxford, UK, pp. 177-212.

Lothenbach, B., Nonat, A., 2015. Calcium silicate hydrates: Solid and liquid phase composition. Cement and Concrete Research 78, 57-70.

MacKenzie, K.J.D., Meinhold, R.H., 1994. Thermal reaction of chrysotile revisited: a ${ }^{29} \mathrm{Si}$ and ${ }^{25} \mathrm{Mg}$ NMR study. American Mineralogist 79, 43-50.

Massiot, D., Fayon, F., Capron, M., King, I., Le Calvé, S., Alonso, B., Durand, J.O., Bujoli, B., Gan, Z., Hoatson, G., 2002. Modelling one-and two-dimensional solid-state NMR spectra. Magnetic Resonance in Chemistry 40, 70-76.

Melekhova, E., Schmidt, M.W., Ulmer, P., Guggenbühl, E., 2006. The reaction talc + forsterite $=$ enstatite $+\mathrm{H}_{2} \mathrm{O}$ revisited: Application of conventional and novel experimental techniques and derivation of revised thermodynamic properties. American Mineralogist 91, 1081-1088.

Merkel, B.J., Planer-Friedrich, B., 2008. Groundwater geochemistry. A Practical Guide to Modeling of Natural and Contaminated Aquatic Systems Springer Berlin.

Mitsuda, T., Taguchi, H., 1977. Formation of magnesium silicate hydrate and its crystallzation to talc. Cement and Concrete Research 7, 223-230.

Nied, D., Enemark-Rasmussen, K., L'Hopital, E., Skibsted, J., Lothenbach, B., 2016. Properties of magnesium silicate hydrates (MSH). Cement and Concrete Research 79, 323-332.

Nied, D., Lothenbach, B., L'Hopital, E., 2011. Synthesis, structural characterization and solubility of M-S-H gel. TN 2011-50 Part 2, Empa technical note.

Plusquellec, G., 2014. Analyse in situ de suspensions de silicate de calcium hydraté: application aux interactions ioniques à la surface des particules. Université de Bourgogne.

Pokrovsky, O.S., Schott, J., 2004. Experimental study of brucite dissolution and precipitation in aqueous solutions: surface speciation and chemical affinity control. Geochimica et Cosmochimica Acta 68, 31-45.

Rhouta, B., Kaddami, H., Elbarqy, J., Amjoud, M., Daoudi, L., Maury, F., Senocq, F., Maazouz, A., Gerard, J.-F., 2008. Elucidating the crystal-chemistry of Jbel Rhassoul stevensite (Morocco) by advanced analytical techniques. Clay minerals 43, 393-403.

Roosz, C., Gaboreau, S., Grangeon, S., Prêt, D., Montouillout, V., Maubec, N., Ory, S., Blanc, P., Vieillard, P., Henocq, P., 2016. Distribution of water in synthetic calcium silicate hydrates. Langmuir 32, 6794-6805.

Roosz, C., Grangeon, S., Blanc, P., Montouillout, V., Lothenbach, B., Henocq, P., Giffaut, E., Vieillard, P., Gaboreau, S., 2015. Crystal structure of magnesium silicate hydrates (MSH): The relation with 2: $1 \mathrm{Mg}-\mathrm{Si}$ phyllosilicates. Cement and Concrete Research 73, 228-237.

Salomão, R., Pandolfelli, V., 2008. Efeito da adição de microssílica na hidratação de óxido de magnésio em concretos refratários (Microsilica addition as anti-hydration technique of magnesia in refractory castables). Cerâmica 54, 43-48. 
Szczerba, J., Prorok, R., Śnieżek, E., Madej, D., Maślona, K., 2013. Influence of time and temperature on ageing and phases synthesis in the $\mathrm{MgO}-\mathrm{SiO}_{2}-\mathrm{H}_{2} \mathrm{O}$ system. Thermochimica Acta 567, 57-64.

Tardy, Y., Duplay, J., 1992. A method of estimating the Gibbs free energies of formation of hydrated and dehydrated clay minerals. Geochimica et Cosmochimica Acta 56, 3007-3029.

Thoenen, T., Hummel, W., Berner, U., Curti, E., 2014. The PSI/Nagra Chemical Thermodynamic Database 12/07. PSI report 14-04, Villigen PSI, Switzerland.

Walling, S.A., Kinoshita, H., Bernal, S.A., Collier, N.C., Provis, J.L., 2015. Structure and properties of binder gels formed in the system $\mathrm{Mg}(\mathrm{OH})_{2}-\mathrm{SiO}_{2}-\mathrm{H}_{2} \mathrm{O}$ for immobilisation of Magnox sludge. Dalton Transactions 44, 8126-8137.

Wei, J., Yu, Q., Zhang, W., Zhang, H., 2011. Reaction products of MgO and microsilica cementitious materials at different temperatures. Journal of Wuhan University of TechnologyMater. Sci. Ed. 26, 745-748.

Welch, M.D., Rocha, J., Klinowski, J., 1992. Characterization of polysomatism in biopyriboles: double-/triple-chain lamellar intergrowths. Physics and chemistry of minerals 18, 460-468.

Yang, J.C.S., 1960. The system magnesia-silica-water below $300^{\circ}$ C.: I, Low-temperature phases from $100^{\circ}$ to $300^{\circ} \mathrm{C}$. and their properties. Journal of the American Ceramic Society 43, 542-549.

Yu, P., Kirkpatrick, R.J., Poe, B., McMillan, P.F., Cong, X., 1999. Structure of calcium silicate hydrate (C-S-H): Near-, Mid-, and Far-infrared spectroscopy. Journal of the American Ceramic Society 82, 742-748.

Zhang, T., Cheeseman, C., Vandeperre, L., 2011. Development of low pH cement systems forming magnesium silicate hydrate (MSH). Cement and Concrete Research 41, 439-442. 
Highlights:

- M-S-H forms very slowly from $\mathrm{SiO}_{2}$ and $\mathrm{MgO}$

- A "transitional" M-S-H with a $\mathrm{Mg} / \mathrm{Si}$ ratio of $\sim 1$ is formed at early age

- $\mathrm{Mg} / \mathrm{Si}$ ratio in M-S-H is between 0.8 and 1.3

- Solubility of M-S-H can be described with a solid-solution model

- Similar solubility of M-S-H, talc and antigorite 